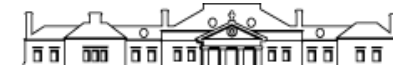

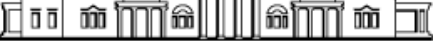

Levy Economics *

Institute

of Bard College

Working Paper No. 933

\title{
Defaultnomics: \\ Making Sense of the Barro-Ricardo Equivalence in a Financialized World
}

by

Lorenzo Esposito*

Bank of Italy and

Catholic University of the Sacred Heart, Milan

and

Giuseppe Mastromatteo

Catholic University of the Sacred Heart, Milan

July 2019

*The views expressed are those of the author and do not involve the responsibility of the Bank of Italy. This work can be seen as an extension and a deepening of previous papers and presentations. A partial anticipation of the present research is also in Mastromatteo and Esposito (2017b).

The Levy Economics Institute Working Paper Collection presents research in progress by Levy Institute scholars and conference participants. The purpose of the series is to disseminate ideas to and elicit comments from academics and professionals.

Levy Economics Institute of Bard College, founded in 1986, is a nonprofit, nonpartisan, independently funded research organization devoted to public service. Through scholarship and economic research it generates viable, effective public policy responses to important economic problems that profoundly affect the quality of life in the United States and abroad.

Levy Economics Institute

P.O. Box 5000

Annandale-on-Hudson, NY 12504-5000

http://www.levyinstitute.org

Copyright (C) Levy Economics Institute 2019 All rights reserved

ISSN 1547-366X 


\begin{abstract}
The 2008 crisis created a need to rethink many aspects of economic theory, including the role of public intervention in the economy. On this issue, we explore the Barro-Ricardo equivalence, which has played a decisive role in molding the economic policies that fostered the crisis. We analyze the equivalence and its theoretical underpinnings, concluding that: (1) it declares, but then forgets, that it does not matter whether the nature of debt and investment is public or private; (2) its most problematic assumption is the representative agent hypothesis, which does not allow for an explanation of financialization and cannot assess dangers coming from high levels of financial leverage; (3) social wealth cannot be based on any micro-foundation and is linked to the role of the state as provider of financial stability; and (4) default is always the optimal policy for the government, and this remains true even when relaxing many equivalence assumptions. We go on to discuss possible solutions to high levels of public debt in the real world, inferring that no general conclusions are possible and every solution or mix of solutions must be tailored to each specific case. We conclude by connecting different solutions to the political balance of forces in the current era of financialization, using Italy (and, by extension, the eurozone) as a concrete example to better illustrate the discussion.
\end{abstract}

KEYWORDS: Barro-Ricardo Equivalence; Financialization; Default

JEL CLASSIFICATIONS: E62; H23; F65 


\section{INTRODUCTION: THE MEANING OF THE BARRO-RICARDO EQUIVALENCE (BRE)}

Public debt has the unenviable record of being blamed for almost every economic disease, at least since David Hume and Adam Smith. In Europe, the process of economic and political unification has the war against public debt at its core, especially after the Maastricht Treaty. The 2008 crisis has worsened the problem because the states were forced to bailout the banking system, thereby increasing public debt. In fact, "public debt has reached unprecedented levels in advanced economies. It has become today the most pressing and difficult policy challenge that Western governments have to face" (Banque de France 2012, 3). Overall financial leverage is at dangerous levels and recently the Governor of the Bank of Italy pointed out: "Additional risks are associated with the high level of global debt, in both private and public hands, which in the third quarter of 2017 reached 245 per cent of GDP, 35 percentage points more than at the end of 2007" (Visco 2018a). The dynamics are well synthesized in figure 1.

Figure 1: World Public Debt-to-GDP Ratio

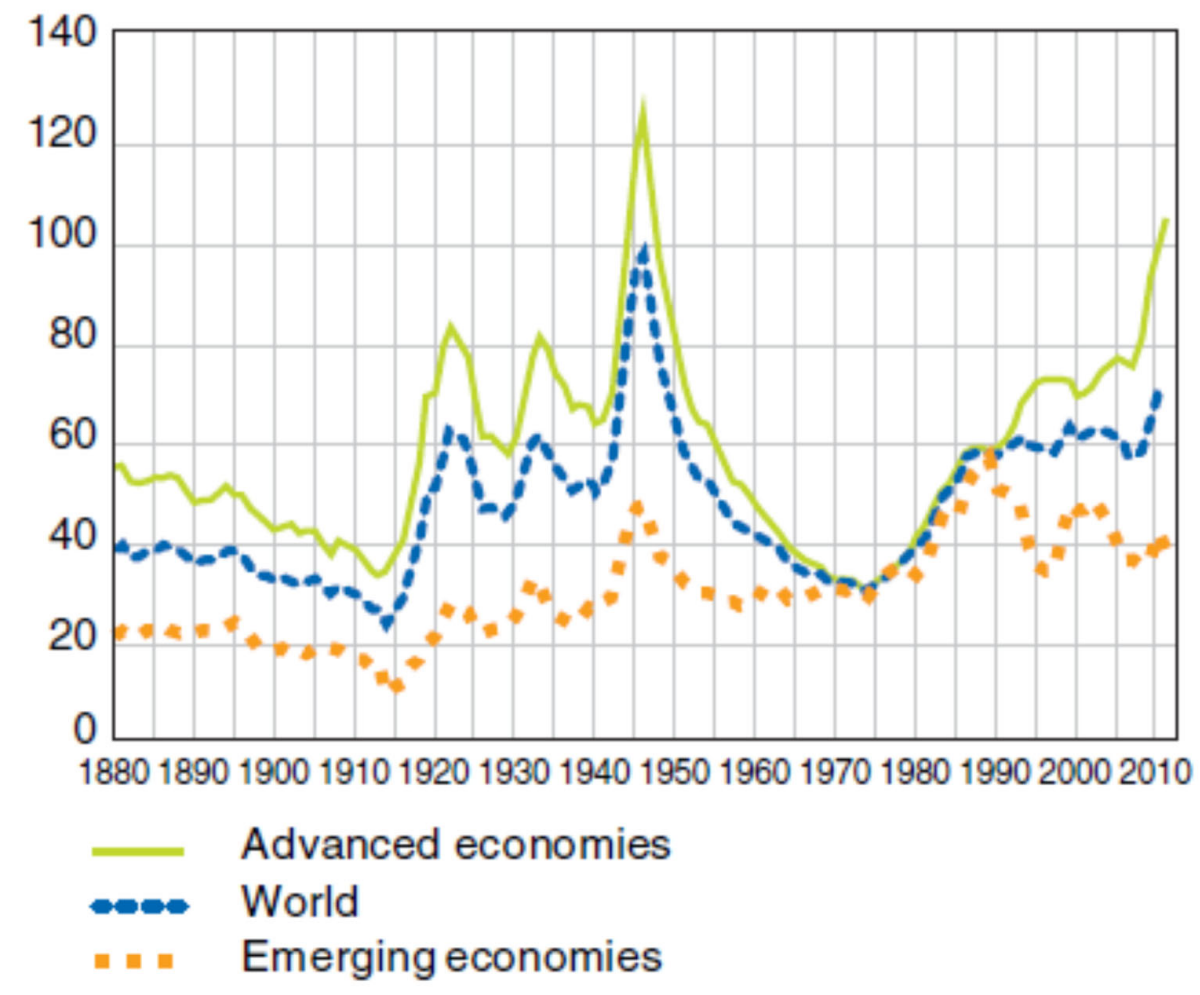

Source: Cottarelli (2012) 
On the theoretical side, the war against public debt coincided with the war on countercyclical policies. In the mainstream paradigm, a market economy is fundamentally stable and financial markets are efficient. So, public institutions are better left out of the picture, apart from an independent central bank that should ensure low inflation. In particular, expansionary fiscal policies are useless: "Any government expenditure crowds out private investment; therefore, loose fiscal policy may in fact be contractionary" (Caballero and Krishnamurthy 2005). This was the macroeconomic wisdom before the crisis. In this framework, the Barro-Ricardo equivalence (BRE) has played a decisive role.

The original article by Barro (1974) explained that it is futile to use public money to boost the economy because private investment crowds it out. Since the problem is public debt, not debt as a whole, these theories, and the BRE in particular, favored an interpretation of debt dynamics that acted as a smokescreen for policymakers. In a scene of the Italian movie Ecce Bombo (1978), a group of youngsters waiting for the sunrise on a beach near Rome are taken completely by surprise as the sun rises at their back (they were facing westward toward the sea). Placing all the emphasis on public debt, the BRE has put economists and policymakers in the same situation, preventing them from having the right perspective on modern finance. The world, and Europe in particular, is paying a heavy toll for this mistake.

In fact, while according to the BRE, it is public debt that was the danger and financialization (i.e., the growth of private debt and financial leverage) was of no concern. The mainstream paradigm does not even have a proper place for money, banks, and finance (Freixas and Rochet 2008), and practically every financial innovation was considered good (securitization, credit derivatives, the originate-to-distribute-model, etc.). Since the 1980s, the weight of the financial system on the world economy has been growing apace. Though mainstream economics did not have any viable explanation for this trend, it was considered a positive development because a bigger role for finance meant more growth and more innovation (King and Levine 1993; Rajan and Zingales 1998). When, in the same historical period, financial crises started to punctuate the world economy, they were explained as being caused by a lack of finance, too many corporate rules, too high corporates taxes, too much state intervention, or crony capitalism (Bell 2008). When the crisis struck at the very heart of the world financial system, these "explanations" fell apart. Although many economists continued to suggest laissez-faire solutions, central banks and governments rushed to rescue the banking system and the world economy. 
Although much has been said about deleveraging, after the banking collapse of 2008, debt has grown even faster (Dobbs et al. 2015; IMF 2018). As for public finance, the public debt trajectory has worsened because of the bank bailout and the crisis itself (Cecchetti, Mohanty, and Zampolli 2010). However, no one seems to be worried about a significant increase in the interest rate; on the contrary, there are studies on how to adjust to a world that is cornered in the zero lower bound (Agarwal and Kimball 2015; IMF 2017). This is because economic agents (states included) have such a high level of financial leverage that a strong increase in the interest rates is ruled out. Before the crisis, central banks (especially the US Federal Reserve) had been criticized for keeping the rates too low. Fed Chairman Alan Greenspan consented happily because he believed in free-market recipes (Greenspan 2009), but besides his personal opinions, the Fed and other central banks did it because they had no choice, as was clear when they attempted to raise rates and the market panicked. This is even truer now. The critiques of fiscal dominance (Bayoumi et al. 2014) are tantamount to the idea that central banks, when deciding their policies, can overlook the $\$ 60$ trillion in public debt and at least three times as much total debt. In the "new normal" - as the IMF defines the present environment for monetary and fiscal policy - the leverage ratio is structurally high and monetary policy has contributed to making it sustainable by keeping down interest rates and buying public debt.

In such a situation, is the central bank really independent? What will be the role of fiscal and monetary policy in the future? Another dimension of the discussion is public debt. Is it a threat to growth and financial stability? How will we deal with mounting public debt?

In this paper, we deal with these topics by analyzing the BRE assumptions and conclusions vis-à-vis the default. In section 2, we extend the theoretical side of the issue, showing that in the BRE world, default is the optimal (or rather the only) outcome for public debt, and we analyze the theoretical consequences of this conclusion. In section 3, we discuss the real world situation vis-à-vis the solutions to high levels of public debt, showing that it is not possible to draw general conclusions on the issue. In sections 4 and 5, we relate practical issues to the specific Italian situation to make the discussion more concrete, although we do not expect to outline a thorough scenario for a possible Italian default. 


\section{THE BRE WORLD}

\subsection{Assumptions and Empirical Truths}

"Neither Ricardian equivalence nor the Modigliani-Miller theorem hold in the real word." (Reichlin, in Corsetti et al. 2015)

The BRE comes with a host of implausible assumptions, as acknowledged even by its supporters. Should we discard it because of them? Let us start by recapping its main assumptions.

1. The application of Say's law implies a full utilization of productive resources, hence no involuntary unemployment, nor idle resources in the system (Arestis and Sawyer 2003). This also means that fiscal deficit is useless because, paraphrasing Smith, "government borrowing would deprive society of resources which could be invested more productively" (Balassone and Franco 2001).

2. There is a strong representative agent hypothesis (RAH), therefore people are "identical in terms of tastes and productivity" (Barro 1974), and what is true for a single agent is also true for the economy as a whole.

3. Although the analysis is not restricted to steady-state situations the economy is completely immobile - no demographic change, no technological change, everything is the same year after year-allowing one generation to assume its preferences will be identical to those in following generations..

4. People are altruistic toward their offspring (intergenerational altruism [Röhn 2010]) and, thanks to assumptions (1) and (3), altruism is understandable because every generation is identical to the previous and following one;

5. There is complete financial autarky (or at least international markets have no relevant influence on the national financial market) (Bulow and Rogoff 1989).

6. There is no potential for Ponzi conditions, meaning that government has a credible commitment to contain its debts (or public debt cannot be rolled over forever) (Tcherneva 2008).

7. Connected to points (4) and (6), there is an assumption of equal length of households' and governments' horizons (de Castro and Fernández 2009).

8. There is an absence of liquidity constraints and borrowing constraints (therefore "safe assets" or liquidity services offered by governments or others are useless). 
9. Capital markets are complete, taxes are not distortionary, and central banks do not exist.

10. Due to the assumptions above — especially points (2), (6), and (9) — public action does not have redistributive effects (De Luzenberger, Imbriani, and Marini 1992). 11. Money is superneutral, i.e., not even its growth rate affects real variables ("superneutrality and Ricardian equivalence have a twin relationship" [Detken 1999]) or, to be more precise, the equivalence holds only if money does not exist [Liviatan 1982]).

On the basis of these points, BRE supporters conclude that, as far as economic growth and interest rate levels are concerned, the amount of public debt and deficit is irrelevant. Fiscal policy cannot help because an increase in public debt today yields higher taxation in the future, and this fact is predicted by taxpayers who will spend less now so as to be ready when taxes rise; therefore, net private wealth remains unchanged and the stimulus effect of the expansionary policy is nonexistent (Barro 2007; Tatom 2009; Forster 2009). To use the words of Hume $(1752,96)$, "it is like transferring money from the right hand to the left; which leaves the person neither richer nor poorer than before." Secondly, public debt is also irrelevant in terms of maturity structure (Greenwood et al. 2014) or as far as future debt stabilization issues are concerned (Rigon and Zanetti 2017). Moreover, public policies have no wealth effects (Arestis and Sawyer 2003, 2004; Koo 2008). Conversely, private debt cannot destabilize the economy because "in the neoliberal framework whatever the private market decides is by definition "right"" (Stiglitz 2014), implying that the risk of every bond or credit is, on average, priced correctly, and thus it will be issued only if it makes economic sense, so a financial crisis is impossible.

BRE assumptions are certainly very strong. As John Seater (1993; emphasis in the original) pointed out: "Ricardian equivalence may seem trivial and hardly worth argument, and indeed it is, given the assumptions underlying the previous statement of it."

This is true for scientific deduction in general, because conclusions are only an (good or bad) application of the assumptions, and here conclusions rest on the assumptions on which the BRE is based (Buiter 1980). But arguably we do not live in a world based on general economic equilibrium assumptions (Eisner 1989), nor is it likely that we ever will. On the contrary, we are moving away from it (Saito 2016). 
As for the factual merits, it is difficult to assess the empirical strength of the BRE because it is difficult to ascertain the effect of a theory on something that does not even exist (like the representative agent or a modern economy without a central bank). Therefore, we cannot really test the BRE as it stands, but only a political conclusion stemming from it (even if in a situation that is very different from the BRE world). Stiglitz (2015) has aptly summed up the proofs as follows: "The empirical evidence is overwhelming that the Barro-Ricardo theorem, and my generalization of it, are wrong" (see also Zezza 2009). For instance, fiscal illusion is widespread (O’Driscoll 1977), international capital markets are relevant (Bulow and Rogoff 1989; Claeys, Moreno, and Suriñach 2012), full employment is an extreme assumption (Arestis and Sawyer 2003), information is incomplete (Pozzi 2006), there are borrowing constraints (Altig and Davis 1989), and interest paid on public debt produce wealth effects (Schlicht 2013, 2014), as well as many other deviations, such as agents' myopia, non-lumpsum taxes, finite horizons, earning uncertainty, and so on (Smetters 1999). In general, fiscal policy is found to be effective, if not much, and the BRE has been "strongly rejected" (Hemming, Kell, and Mahfouz 2002). On top of that, an empirical appraisal of the BRE is very difficult due to important measurement and methodological issues to be accounted for (Haug 2016). This point is especially relevant because what can be tested are aggregate variables that are not micro-founded unless we assume that the RAH holds (Bernheim 1987; Pozzi 2006). Given that the BRE has a strong microeconomic content, it seems more useful to employ surveys instead (Ricciuti 2003) but these studies are generally not consistent with the BRE (Hayo and Neumeier 2016).

Barro (1988) himself took many empirical objections to the equivalence into consideration. In particular he elaborated five empirical objections - finite horizons, imperfect loan markets, uncertainty about future taxes, non-lump-sum taxes, and involuntary unemployment - concluding that the BRE is like the Modigliani-Miller theorem: literally implausible, but useful for discussing different scenarios.

Connected to this idea is the strand of literature that analyzes if the BRE holds in specific contexts. These authors find, for instance, that the results are different in different countries and depend on if deficit is used for public investment or to cut taxes (Röhn 2010), they are also different according to the public debt/GDP ratio (i.e., taxpayers are Ricardian - in that they predict future taxes will increase if current public debt increases - only when the ratio is high [Nickel and Vansteenkiste 2008]). Needless to say, these conclusions cast doubt on the 
theoretical strength of the equivalence: it is difficult to explain why, for example, Italians behave according to the BRE and Germans do not, or why the BRE holds only with specific compositions of the public budget. It would make sense only if we introduce a whole series of institutional and historical features into the model, thus making its basic assumptions useless. The results are also mixed when some assumptions are relaxed, for instance, rational expectations (Evans, Honkapohja, and Mitra 2012).

A particularly important point concerns the RAH, because an economy based on the RAH prevents many things from happening and, because it makes redistributive policy futile, it rules out every conclusion on the distribution of wealth among individuals, as Tobin (1952) pointed out. It is then obvious that a model with different types of consumers has "dramatic consequences" for the BRE (Jacobs 2012; see also Woodford 1990; Smetters 1999). The RAH also excludes political life by positing that we cannot have a strategic interaction between politicians and voters (as, for instance, in Barseghyan and Coate [2014]), because all voters are identical: there is a single agent in the economy that cannot but elect himself to the government. As Bernheim (1987) observed: "If the world was otherwise Ricardian, then one would never expect to observe deficits since the electorate would universally oppose the gratuitous introduction of uncertainty." For sure, "there is no need for government lending" (Canzoneri, Cumby, and Diba 2013). Nor can public debt be considered as "an attractive alternative for policy makers" to delay taxes (Gogas, Plakandaras, and Papadimitriou 2014) because it is incompatible with RAH. The RAH also rules out the role of government bonds as "safe assets" because investors do not need to be protected from the crisis, while in the real world we find public debt used to that end (Greenwood et al. 2014). Politically speaking, the most important recent empirical discussion has been the effectiveness of fiscal policy in helping to spur growth without effects on inflation and most of the studies conclude this is not a possible outcome for the BRE (Boitani and Perdichizzi 2018).

All the aforementioned objections to the BRE make sense. However, we start ignoring them to introduce our point, but reconsider them later. 


\subsection{Default in the BRE World and Beyond}

"Bankruptcy is a central part of modern capitalism." (Stiglitz 2001)

The BRE states that public debt is only a different way to impose taxes. Citizens will realize it and will be ready when taxes come. This is why in BRE models, public debt is typically not an investment, but a tax break that will be siphoned off from the system at a later stage. Now, if public debt cannot improve the situation, by the very same token, it cannot worsen it. As Barro (1974) concluded: "there is no persuasive theoretical case for treating government debt, at the margin, as a net component or perceived household wealth." This means that for the representative citizen (RC), the present value of public bonds they holdnetted from the taxes they will be forced to pay-is always zero. We describe this situation in table 1 , where $\mathrm{B}$ is the government bond issued at $\mathrm{t}=0$ and paid in $\mathrm{t}=\mathrm{H}$ and $\mathrm{r}$ is the interest rate on $\mathrm{B}^{2}$. Then we have:

$\begin{array}{lccc}\text { Year } & \begin{array}{c}\text { Asset held } \\ \text { by the RC }\end{array} & \begin{array}{c}\text { Amount received } \\ \text { by the RC }\end{array} & \begin{array}{c}\text { Amount paid } \\ \text { by the RC }\end{array} \\ 0 & \text { B } & 0 & -B \\ 1 & \text { B } & \text { rB } & \text { rB } \\ 2 & \text { B } & \text { rB } & \text { rB } \\ \ldots & \ldots & \ldots & \ldots \\ \text { H-1 } & \text { B } & \text { rB } & \text { rB } \\ \text { H } & \text { B } & \text { rB } & \text { B }+ \text { rB } \\ \text { H+1 } & 0 & 0 & 0\end{array}$

Source: Seater (1993)

The idea is that the $\mathrm{RC}$ receives his quota of $\mathrm{B}$ in $\mathrm{t}(0)$ and repays it just as it was a loan. The $\mathrm{BRE}$ rests on the idea that what the $\mathrm{RC}$ receives is exactly what he will pay in due time. Now, let's suppose that in $\mathrm{t}(\mathrm{H}-1)$ a new government is elected and it defaults on public debt. What will change for the RC? Nothing. They will have fewer assets and therefore fewer taxes to pay. As public debt cannot do anything when it appears, it cannot do harm when it disappears. In the BRE world, default is the rational solution to public debt—it determines

\footnotetext{
${ }^{2}$ We could use a more mathematically sophisticated representation, as in Barro (1979), Schlicht (2013, 2014), etc., but the final result would be the same, so we stick to the simplest possible representation. A method that could also help in understanding the issue is the stock-flow consistent approach (SFC), which allows for a clear treatment of the financial interdependencies of the economic sectors and whose application confirms our analysis. Although SFC scholars do not normally use the BRE, it can be used to close an SFC model (Nikiforos and Zezza 2017, 29; see also Le Heron 2012, 269-70).
} 
the sudden disappearance of all the future additional taxes while everything else remains unaffected. In fact, a rational government would default as soon as possible on public debt, because that would force a cut in taxation - the only cut that is a net increase in the RC's wealth — while a normal cut (which in the BRE world means an increase in public debt) would mean more taxes at a later time. Barro (1976) had already explained a similar idea: "If government bonds are not perceived as net wealth, then the demand for bonds rises one-toone with the supply, there is no change in interest rates, and no displaced private borrowers." Given that default is the rational solution for public debt, a rational $\mathrm{RC}$ would not even waste time buying public bonds because they know that default will come as soon as possible. Indeed, it is impossible to see how it has not yet occurred. In the BRE world, if citizens and government are rational, public debt cannot exist.

\subsection{All That Is Bond Does Not Glitter: What If the Default Is Already There and We Don't Know}

"At the heart of the debate on Ricardian equivalence is the question whether bonds should be considered as net wealth or not." (Detken 1999)

In the BRE world, public bonds crowd out other financial assets (Konzelmann 2014;

Richardson 2015). The total amount of investment (and hence of debt) is fixed, because the BRE holds true that in the economy there is always the full utilization of capacity. Therefore every meaningful investment has already been made. The crowding out happens with corporate bonds but also with equity because "equity and government bonds [are] perfect substitutes" (Barro 1974). This is a very dubious conclusion, as is clear from "flight to quality" episodes (such as the eurozone spread crisis of 2011). Nevertheless, let us take it as valid and see what comes from it. In an analogy to the quantity theory of money, as economic resources are fully utilized, investment or consumption cannot go up when the central bank prints more money or when government makes more debt. In this framework, fiscal policy can only substitute private with public investment, which does not create more wealth, but only shifts it among generations. Therefore, public investment and debt cannot do any good, nor can private investment and debt do any harm. Their substitutability only operates in one direction: once private debt has been created, it can be crowded out by public debt. In this context, the use of countercyclical policies is irrelevant because public debt cannot be used to increase economic growth or employment. As for the crowding-out effect, 
it can also happen among private firms and not only between public and private borrowers (OECD 2017).

This is true even if in the BRE world public bonds are fully secured because "the amount of bond issue would be limited by the government's collateral, in the sense of its taxing capacity" (Barro 1974), although private debt can be unsecured as well. In reality, the fact that public debt is collateralized by taxes helps to explain why it is rolled over forever (Caballero and Krishnamurthy 2005). In addition, Barro (1974) also objects to the role of government bonds as "safe assets" because "liquidity services can also be provided by private producers." We will come back to the meaning of liquid assets. For now, we only point out that at least from the time of Walter Bagehot in the late 19th century, backstops against financial crises have been put up by the state via lending of last resort activities and extensive recapitalization of the banks. At any rate, the BRE is based on a contradiction: if public and private bonds are such close substitutes that they can even be used indifferently as safe assets, every conclusion that is true for public bonds must also be true for private debt and vice versa. For instance, Barro (1974) points out that "the future interest payments on the government debt must be financed in some manner." Whatever this means, it is also true for private bonds and, if an increase in public bonds implies more taxes in the future, this is also true for an increase in private debt. It is easy to show that because bonds are assets for some and a liability for others, bonds (public or private) can never be net wealth or, as Duménil and Lévy (2012) put it, "the total net wealth of all agents is necessarily null." Unfortunately, this inevitable conclusion never comes out in the BRE literature. If we take the BRE's hypotheses seriously, there is no difference between public bonds and financial wealth tout court.

In this way, the discussion of the difference between public and private debt in the BRE context brings us to a fundamental aspect of economic theory: What is wealth? Barro (1974) concluded that public debt is not wealth because "there is no persuasive theoretical case for treating government debt, at the margin, as a net component or perceived household wealth." Unless there is a default, a person that holds government bonds has net wealth. This is not under question. What the BRE implies is that, socially, government debt cannot be net wealth but only a shift of income among people. However, the BRE is based on the RAH: all households are identical, so what is true socially (i.e., public bonds are not wealth) is also true individually. Therefore, if public bonds are not net wealth overall they cannot be wealth 
for anyone. Knowing this, why should a rational investor buy public bonds? In reality, in an RAH context, as we have seen, bonds in general are not net wealth, as the RAH removes any financial dimension from economic analysis. This illustrates the more general point that we cannot analyze social wealth using methodological individualism, which is, technically speaking, limited to partial equilibria. This illustrates the more general point that we cannot understand money (and therefore wealth) as though it was a product of isolated individuals. Its function is to allow independent producers to exchange and accumulate values (i.e., wealth) and it is possible only if this function is acknowledged at a social level so that producers can exchange their private products with social wealth (money).

Let's illustrate this fallacy with an example. In a country there are one million households living in similar representative houses worth $\$ 100,000$ each and national statistics register the situation putting the overall (real estate) national wealth at $\$ 100$ billion. During a year, 5 percent of these houses are bought and sold for $\$ 110,000$ each. At the end of the year, every household reconsiders its real estate wealth using the last price available, which is then also used for national statistics, making the overall real estate wealth of the country $\$ 110$ billion. Is this a real increase? Before the crisis, Debelle (2004) asked aptly: "Do rising house prices increase household welfare?" For years the house was used as collateral to finance consumption, so the increase seemed real. This is why house-price bubbles played a major role in the world crisis (Jordà, Schularick, and Taylor 2015). In reality, this increase rests on the hypothesis that everything will go on smoothly. If the country is hit by a crisis and many households are forced to sell their homes, they will find no buyers and the price would collapse. They will rapidly learn the difference between the micro and macro dimensions of theoretical wealth and real liquidity. The conclusion should be obvious and has, in fact, been noted many times. As early as 1720 , John Law, who was one of the finest monetary economists of his century - although now famous for his failures - proposed the very same argument. He asked: What if the citizens of Paris, where most of real estate wealth of the country is, all sell their properties abruptly? "This frenzy, if it occurred, would reduce to nothing the most priced houses and properties." 3 This is what happens to every financial market during sell-off days. Indeed, the hidden assumption that financial assets are liquid is also behind international accounting standards, financial regulators' stress tests for banks, and value at risk (VAR) models for risk management. Basically every policy tool and risk

\footnotetext{
3 “Cette frénésie, si elle avait lieu, réduirait à rien les maisons et les terres les plus considérables” (Law 1934, III, 110).
} 
metric is based on normal prices: that is, the idea that market is stable and in partial equilibria. This is also true for statistics on wealth based on financial and real assets. This also explains why lending is procyclical. When home or financial asset prices go up, banks lend more because the collateral is worth more, thus increasing overall financial leverage. It is rational for the bank but dangerous for society as a whole. Looking at the overall picture, "the confusion of microeconomic and macroeconomic arguments becomes immediately obvious" (Jakab and Kumhof 2015). This is what allowed the "great moderation," but also the 2008 crisis: financialization is behind both epochs.

If we grasp the true content of Law's argument, what about bonds being "net social wealth"? The wealth of a nation that is contained in financial assets (but also real assets) can be considered social wealth only potentially. Two elements are needed to make effective what is only potential: the projective convention (Dequech 2011) and the liquidity convention. Financial assets are priced implicitly assuming that tomorrow there will be no Armageddon. This reasonable assumption, which holds true most of the time, brings us to J. M. Keynes's famous analysis of how markets work. In chapter 12 of the General Theory, Keynes ([1936] 2018,133 ) points out that due to uncertainty, investors do not have statistical data to predict the future rationally, so they resort instead to a social convention to choose the best investment strategy: "In practice we have tacitly agreed, as a rule, to fall back on what is, in truth, a convention. The essence of this convention - though it does not, of course, work out quite so simply — lies in assuming that the existing state of affairs will continue indefinitely, except in so far as we have specific reasons to expect a change."

The micro characteristics of assets are also derived from the social nature of the convention. For instance, the safety of a given asset "does not depend only on the characteristics of the issuer, it is also determined by the features of the market in which the asset is traded" (Gourinchas and Jeanne 2012). Without macrostability, wealth at the micro level also disappears as soon as the asset is put on the market. Stability means liquidity and liquidity needs a social illusion, because, as Keynes ([1936] 2018, 136) observed: "there is no such thing as liquidity of investment for the community as a whole.” To keep financial assets liquid, markets need the state, in operational terms, the central bank as a lender of last resort (Revell 1975). Private assets are interesting to people that own them as long as there are markets where they can be sold and be transformed into social wealth (money), and markets exist if there is liquidity. Mainstream economics rules out instability, just like it rules out 
involuntary unemployment. However, in 2008, as in any previous panic episode, what stopped the collapse and allowed financial assets in private hands to remain social wealth was the role of the state. The government and the central bank assure the good functioning of the market, i.e., liquidity. In other words, private bonds are net wealth as long as the state allows them to be, for instance, with lending of last resort or fiscal policies that protect the economy from financial instability. After 2008, governments issued (and central banks bought) safe assets to check the panic, thus showing that these bonds do have a liquidity service to offer (Woodford 1990) and, inasmuch as government bonds are an important component of financial markets as liquid assets, they are net wealth (Greenwood et al. 2014).

Because sovereign bonds make the composition of wealth more liquid, as Tobin (1952) wisely observed, it is public bonds that allow private debt to become social wealth. ${ }^{4}$ Concretely, government bonds can be used as collateral (Angeletos et al. 2013) under the notorious Bagehot rule, ${ }^{5}$ so that central banks can restore stability by lending of last resort. As we observed, Barro and others proposed the idea that liquidity services can come from private bonds, but under conditions (such as no uncertainty, as in Holmstrom and Tirole [1998]) that make crisis impossible in the first place and hence liquidity irrelevant. Once again, in science, assumptions dictate the relevance of conclusions.

Liquidity - that is, the immediate marketability of financial asset — makes them social wealth (Orléan 2004). Given that liquidity is not only a specific characteristic of an asset, but depends on the overall condition of the markets, the answer to the question of whether (government and private) bonds are net wealth can be answered only by taking the prevailing economic policies into account, which is somewhat similar to the Lucas critique but in an opposite context. The answer to Barro's question of whether government bonds are net wealth is therefore the following: it is not relevant whether debt is public or private as long as markets are stable and bonds are tradable. Without knowing market conditions, no bond is net wealth. If we renounce the illusory world of representative agents, then wealth,

\footnotetext{
${ }^{4}$ We remind the reader that the discussion on what is social wealth cannot be expanded on in an RAH framework. Therefore, even interesting analysis based on this scenario is scientifically untenable. For instance, Röhrs and Winter (2015) pose a very important question connected to the discussion we are facing here: "To what extent is public debt private liquidity?" The problem is that this question cannot be posed in an RAH world where social and private wealth are the same because every individual is identical to every other, so their wealth is just the same.

${ }^{5}$ In Lombard Street, Bagehot (1873) proposed that to tame a panic, the Bank of England should "quickly, freely and readily" offer to every operator whatever liquidity it needed, although at a penalty rate.
} 
liquidity, and efficiency of the markets are macro-attributes and can only be understood as such.

This analysis has also consequences for the connection between financial assets and default. Without the visible public hand, prima facie, all financial assets are worth nothing; that is, they are already in default. Not only is default the only rational policy for public finance under the BRE, it is the ordinary condition for finance in general if social conventions do not prevent it or, to put it more bluntly, if social conventions do not keep investors under the illusion that their investments are liquid (this is an illusion that dries up during market turmoil).

\section{DEFAULT IN THE REAL WORLD}

\subsection{BRE Assumptions and the Situation on the Ground}

We have seen that default on public debt in a BRE world is the most efficient outcome in every situation, therefore issuing public bonds makes no sense. We have also seen that, if for some reason a country has amassed public debt, on the basis of the BRE, immediate default is the most effective policy conceivable. This conclusion is true when BRE hypotheses hold. We do not intend to discuss here in general how economic theory deals with public debt; we are only trying to assess what happens when we remove BRE assumptions, starting with the least significant and then proceeding to the most important, i.e., hypotheses (1) and (2) in the above list. 
Assumption

(3) The economy is completely immobile

(4) Intergenerational altruism

(5) Financial autarky, international markets have no relevant influence on the national financial market

(6) No Ponzi game condition (public debt cannot be rolled over for ever)

(7) Equal length of households' and governments' horizons

(8) Absence of liquidity constraints and borrowing constraints, capital markets are complete

(9) Taxes are not distortionary, central banks do not exist

(11) Money does not exist or at least is superneutral

\section{Comments}

Since public debt is not used to change the economic landscape (innovation, productivity, etc.), if the economy includes demographic and technological changes, default does not affect these paths per se.

If public debt is used to reduce taxes now, therefore leaving payment to future generations, the present $\mathrm{RC}$ could postpone default, while the generation that is called on to pay the debt will default on it and the old generation will not be paid. This is a rational behavior, therefore the old generation will not issue public bonds because their heirs will not reimburse them.

If public debt is at least partially owned by foreigners, part of the tax reduction allowed by public debt will not be deleted by the default. Of course this is linked to reputation, credibility, etc.

In reality, governments normally roll over public debt forever. In fact, default is the only way to assure there is no Ponzi game condition.

A government administration normally lasts a lot less than the life of a citizen therefore its goals will have a narrower horizon. If their horizons are the same, it is more likely that the government will implement the best policy for the RC, i.e., the default.

The BRE assumes that the government will issue public debt that it can sell on the market (and will default on it). In practice, there are constraints linked to credibility, inflation, etc.

If taxes are not lump sum, default will affect some citizen more than others. If central banks exist, as it is always the case, it is a lot easier to issue and trade public debt. This is the original mission of central banks. Public debt in the hands of the central bank is also easier to default on.

If money is not neutral then active monetary policies are, Neutral broadly speaking, more effective (including a default).
Effects on default Neutral

Neutral

Positive $^{6}$

Positive

Positive

Neutral

Positive 
All in all, removing the assumptions does not change the conclusion: default is still the best outcome for public debt, although there are important practical issues left open for debate. We are now going to discuss the two main hypotheses behind the BRE: Say's law and the RAH.

If Say's law does not hold and the economy is prone to crises, countercyclical policies can help, including a selective public debt default. Whether default makes sense or not becomes a practical issue. The most decisive assumption of the BRE is the RAH, which implies that debt is irrelevant. If every economic agent has the same income, assets, debt, and pays the same (lump sum) taxes, an increase in debt—public or private- - is irrelevant. In this situation, default literally does not change a thing; it is only an accounting operation. If the world is not RAH compliant, it is impossible, a priori, to state whether the default is good or bad. Once again it is a practical issue.

BRE assumptions are extreme and it is difficult to see how the real world could ever get close to them, although this has never prevented economists from using the BRE and other models based on similar hypotheses to lecture policymakers. On the basis of the BRE assumptions, default seems the most viable solution for reducing public debt. One could ask why then, although defaults are common (Reinhart and Rogoff [2009, xxxi] speak of the "near universality of default"), can public resistance to default be quite strong? We identify three main reasons for this. As we are dealing here with practical issues, we do not try to detect which BRE assumption is compatible with or relevant for the discussion.

The first reason is the idea that public debt is used to pay for public services, therefore defaulting on it means closing schools and hospitals, laying off firemen and police officers, and so on. Empirically, this is not true if, along the cycle, the country has a "permanent primary surplus" (Buiter 1993), i.e., taxes are enough, on average, to pay state expenses. We synthetize this condition as follows:

$$
\sum_{i} T_{i} \geq \sum_{i} G_{i}
$$

where $\mathrm{T}$ is taxes, $\mathrm{G}$ is the state's expenditures, and interest rates and inflation are so low-as it is the case now in most OECD countries - that they can be left out from the analysis without problem. 
If equation (1) holds, public debt has nothing to do with the supply of public services, although the media can still conflate the issues for political reasons.

The second point is the simple and obvious fact that bondholders will lose money in excess of taxes that they will avoid paying with the default (for instance, because they don't pay many taxes in the first place through tax evasion, loopholes, or fiscal havens, or because financial wealth was inherited and so on). We synthetize the second condition as follows:

$$
B \geq \sum_{b} T_{b}
$$

where $\mathrm{B}$ is public debt and $\sum_{b} T_{b}$ is the sum of taxes paid by bondholders during the lifetime of the public debt they hold.

Equation (2) means that if the taxes paid by bondholders are worth less than the amount of public debt, default is good for the economy at large. Even if in a non-RAH world default is not Pareto efficient - bondholders will not be better off - it can still be the best policy for the majority of citizens (especially when financial wealth is highly concentrated). However, it can be difficult nonetheless for other reasons (political power of bondholders, international reputation, and so on).

The third reason is financial disruption. Default on public bonds can throw the financial system into a state of chaos that will affect the whole economy, even if default, per se, could make sense. We point out that preventing this havoc from materializing is a matter of political discussion and cannot be dealt with in a mainstream context. So let us abandon the BRE framework, where default is always the best solution, and move to the real world to discuss if it still makes sense.

\subsection{Why the Default and Where the Public Debt Comes From}

"All modern finance, the whole of the banking business, is interwoven in the closest fashion with public credit." (Marx 1867)

There are considerable controversies on how dangerous public debt is and at which debt-toGDP ratio it starts to be a serious threat (Visco 2017). Different studies find different thresholds in different situations. For instance, Caner, Grennes, and Koehler-Geib (2011) 
find it is 77 percent for developed countries and 64 percent for developing ones. These empirical analyses are based on an average of different countries and periods, representing a number that is not particularly useful in any concrete situation (Fiebiger and Lavoie 2017). However, we can agree that high debt "represents a deadweight burden on the economy, dimming both its investment and growth prospects" (Ostry, Ghosh, and Espinoza 2015). Moreover, the problem is mounting, because public debt growth has been strong since the 2008 crisis. For instance, in the eurozone it is now at 87 percent, which is 22 percentage points higher than it was 10 years before (Bank of Italy 2018a, 34).

Public debt can be faced in different ways. First of all, it can be slowly reduced using fiscal surpluses linked to economic growth. However, as Smith ([1776] 1904, 725) already observed: "When national debts have once been accumulated to a certain degree, there is scarce, I believe, a single instance of their having been fairly and completely paid." This also because a crisis can destroy decades of fiscal prudence. The possibility of a crisis also explains why a simple rollover of the debt ("it is better to live with high debt than to pay it down" [Ostry, Ghosh, and Espinoza 2015]) cannot prevent problems later on. In practice, either the debt is ignored (i.e., it is left to the ordinary surpluses to reduce it in the good times of the cycle) or it is faced squarely, but "to make a serious dent in debt ratios, austerity will need to be substantial and sustained" (Mody 2013). All choices are dangerous. We should add that fiscal stimulus is not conducive to an increase in the debt-to-GDP ratio unless the ratio is already very high (Auerbach and Gorodnichenko 2017).

A second option is using inflation or devaluation to reduce the real repayment. This was called a "pretended payment" by Smith ([1776 1904]), who considered it worse than a real default. For sure, it can be as disruptive as a proper default or even more, as shown in historical events like the Weimar hyperinflation, because effects cannot be limited to public debt. For instance, the effect of a strong inflation on income and wealth distribution can be, by far, stronger that those coming from a default. While default is a one-off event, inflation is a process that is not easy to tame or dispose of. Moreover, higher internal inflation means a competitive disadvantage for domestic firms vis-à-vis their competitors, while default does not directly change their relative position in the market (for Italy, see Rey and Peluffo [1995]). We do not need to turn to an extreme example like the Weimar hyperinflation to appraise how dangerous an uncontrolled inflation can be. For sure, these episodes show the 
complex interlinkages among inflation, public finances, and devaluation (Bresciani-Turroni 1937).

A third option is monetization - that is, using the central bank to buy a sizable part of public bonds. Monetization is similar to a rollover in the sense that the debt is not reduced, but it is frozen. In the current epoch, the most successful example of monetization is Japan where, although the debt-to-GDP ratio is around 250 percent, inflation and the debt service ratio appear to be under control because most of the public debt is held by the Bank of Japan and domestic financial intermediaries (Minenna 2018). This is interesting because many economists pointed out that a high level of public debt can make inflation or default more likely (Buiter 1993). All in all, we acknowledge that a rollover of the debt (included monetization) can still end with a default, force austerity (that is cuts to public services, unemployment, etc.), cause inflation, or a combination any of them. However, monetization has the merit that it can buy time. The aforementioned possibility of a permanent rollover has been considered viable when interest rates are low, as in the decade after the 2008 crisis (Blanchard 2019). This solution, like monetization, is a good way to buy time, but a risky one in uncertain times.

A fourth option is a "steady dosage of financial repression" (Reinhart and Sbrancia 2011), for instance pushing domestic banks to buy public bonds (also using favorable prudential regulations $^{7}$ ), capping rates on alternative investment, and so on. Although this solution proved to be very successful after World War II, in the present global financial system, rules on a national level are difficult to enforce and easy to escape.

The last option (a partial or total default), is the quickest and surest way to dispose of the problem, "the measure which is both least dishonorable to the debtor and the least hurtful for the creditor" to quote Smith ([1776] 1904, 726), although it should be treated with caution. In a sense, it is like the strongest and bloodiest weapon in a war, to be used as the final measure.

\footnotetext{
${ }^{7}$ This was particularly true in the Basel 1 framework but it is true also now. As Tirole observed: "Under current Basel rules, risk weights for sovereign debt rated AAA to AA- are still 0 percent. ... The low capital requirement, together with a new demand for 'liquid' assets to satisfy the liquidity coverage ratio, creates a strong incentive for banks to hold sovereign debt" (Dewatripont, Rochet, and Tirole 2010, 232; see also BIS 2017).
} 
Historically speaking, default is a common trait of financial history worldwide. Reinhart and Rogoff (2009) documented at least 250 external and 68 internal sovereign default episodes between 1800 to 2009, which add up to more than one-and-a-half per year on average since the Industrial Revolution, as shown in figure 2.

\section{Figure 2: Frequency of Sovereign Defaults}

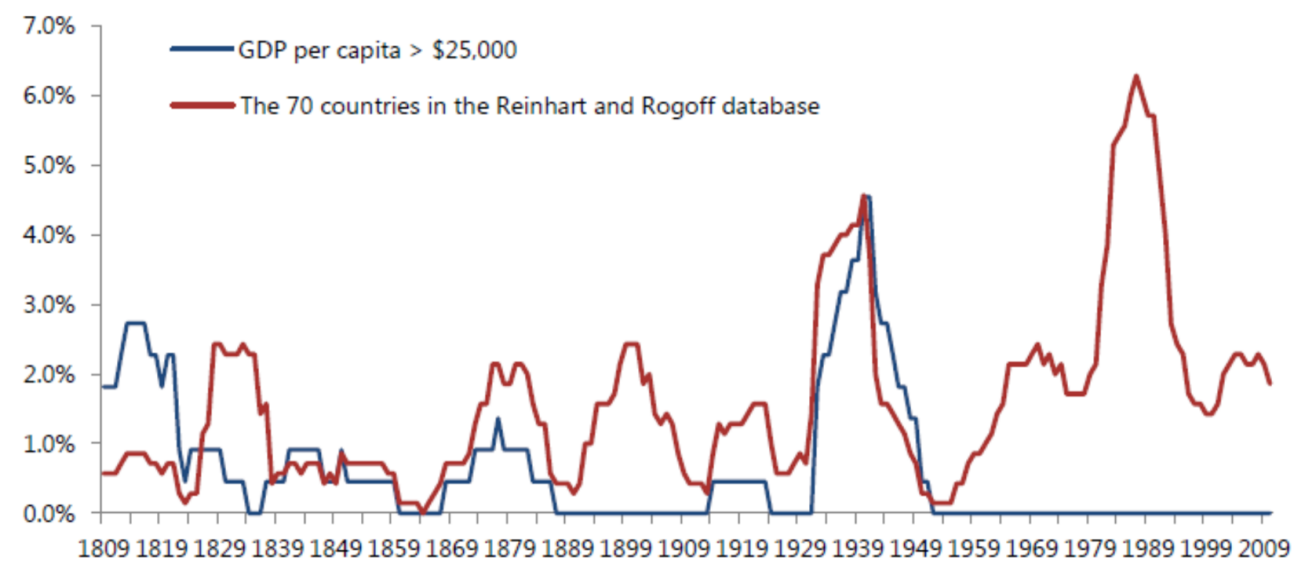

Source: BIS $(2017,6)$

They also found that these defaults came under very different conditions, including a variety of debt/GDP ratios (in only 16 percent of documented episodes was the ratio higher than 100 percent). The world has witnessed 319 defaults and can well survive the 320 th. The situation has even worsened in recent times: Asonuma and Trebesch (2016) report 179 public debt default episodes between 1978 and 2010 (that is almost six a year), while Das, Papaioannou, and Trebesch (2012) documented 600 cases of debt restructuring between 1950 and 2010, although they were all in emerging markets. Depending on the situation, the default can have very different features and yield different results in terms of growth, financial stability, wealth distribution, and so on. We will come back to these differences later.

Broadly speaking, there are many reasons why it is difficult to assess which solution is the best, because they typically come around in combination (for instance "a mix of austerity, forbearance, and growth" [Reinhart and Rogoff 2013]) and it is hard to disentangle the specific effect of a single solution. Moreover, in a non-RAH framework, it is not clear what success looks like. Different solutions affect different people, and a solution that is preferred by a majority of voters can still be rejected by the markets, with serious consequences for economic growth. Moreover, policies used to avoid public bond default entail a default, too, because they imply a serious change in the net present value of citizens' income, if not for 
the bondholders' income. For instance, the many pension reforms passed in Italy between 1992 and 2008 reduced the pension coverage ratio by almost half (Casadio, Paradiso, and Sarcinelli 2009, 548). In practice, the state defaulted on its future pension duties. Reforms or austerity are tantamount to restructuring the debt that the state has with citizens in terms of pensions, public services, and so on. Pension reforms or a public debt write-off are basically different forms of the same policy: they reduce future state liabilities at someone's expenses (this is also what the BRE states). For instance, in the late 1980s in Italy, the yearly payment of interest on the public debt cost the state the same amount as the entire personal income tax, so that "the Italian government could have stopped paying interest on its debt and abolished the personal income tax, in a revenue-neutral fiscal manoeuvre! With top marginal tax rates above 50 percent in Italy, even conservative estimates suggest that such a default policy might have led to substantial gains in the form of increased labour supply and productivity" (Alesina et al. 1992). This advice made sense, but did not have much luck.

The same conclusion holds true for ultra-loose monetary policies that reduce gains on public bonds. For instance, in the United States, monetization has reduced 10-year bond yields between 90 and 200 basis points since 2008 (IMF 2013a). Considering that since 2008 more than $\$ 3,000$ billion in US Treasury securities have been issued, this means around $\$ 27-60$ billion less every year. Therefore, bondholders have sustained a loss under this policy, just like pensioners or beneficiaries of welfare state services in the previous example. We can also see a mix of different kinds of losses. A historical example comes from post-World War I sequential defaults. It is true that foreign countries' default cost the United States around 15 percent of its GDP, but the US in its turn had basically defaulted with the abrogation of the gold clause (that allowed creditors to be paid in gold instead of in dollars), which provoked a debt haircut of 40 percent for US creditors (Reinhart and Rogoff 2013). It has been observed that "when the state itself defaults on its obligations, the rule of law inevitably is harmed" (Buiter and Rahbari 2013). This can be true, but the rule of law is also harmed when the state cuts pensions and welfare services because there is always an (formal or informal) agreement between a government and its citizens that is at stake; the same was true in the case of the implicit haircut on US debt we mentioned. Public debt is a political issue and it is the political balance of forces that decides who will be called on to pay it back. This is why Buiter and Rahbari (2013) rightly point out that "political considerations play a much larger role when sovereign debt restructuring is the name of the game." On a macroeconomic level, in a situation of strong wealth and income concentration, austerity can 
be more recessive than default. But this argument can be inconclusive, especially because, once again, actual consequences will come from the management of a specific default.

It is important to point out, however, that a default has limited effects in the medium run. Economists do not agree on what the costs of a default actually are, because after the restructuring process financial markets do not discriminate between defaulters and nondefaulters, these episodes don't have enduring impact on bond ratings (Borensztein and Panizza 2008), and access to the market seems very similar between countries that defaulted and those that did not (De Paoli, Hoggarth, and Saporta 2006). Overall, "sovereign states often are able to borrow again soon after default" (Grossman and van Huyck 1988). This was true even long ago. As Eichengreen (1991) pointed out: “Countries that faithfully serviced their debts in the 1930s did not enjoy superior credit-market access subsequently." If the default premia can be negligible, output losses, as well as banking system disruption, can be more substantial (Das, Papaioannou, and Trebesch 2012), but again this is a case-bycase scenario where the political management of the postdefault situation is the main factor.

The choice to default is a matter of alternatives. Of course it is questionable what a "better" alternative really means. For instance, a solution can be better in the short term but not overall, it can be better for domestic savers but not for international investors, and so on. Moreover, the point is whether the default is part of a wider strategy for revamping growth or if it is only a last option in a distressed situation. If economics is not able to deny or confirm that default is the best outcome vis-à-vis its alternatives, we propose a point in its favor: financialization. Public debt management was the main engine for the development of the first wave of financialization in the historical span from Ricardo to Marx (De Cecco 1979; Kindleberger 1987). Modern financial markets were not created to trade corporate bonds or equities, but public debt, and this changed the landscape of the economy. As Marx ([1867] 1887, 535-36). observed: "The public debt becomes one of the most powerful levers of primitive accumulation ... apart from the tax-farmers, merchants, private manufacturers, to whom a good part of every national loan renders the service of a capital fallen from heaven - the national debt has given rise to joint-stock companies, to dealings in negotiable effects of all kinds, and to agiotage, in a word to stock-exchange gambling and the modern bankocracy." After the 2008 crisis, it was clear that bankocracy (that is financialization) is stronger than ever. Creditors are more and more able to impose their terms on the states. For instance, comparing the public defaults of the 1980s and 2010s, Barkbu, Eichengreen, and 
Mody (2012) note: “All countries centrally involved in the 1980s debt crisis ultimately underwent debt restructuring. Payment relief was seen as an important supplement to official financing in this era when financing packages were relatively small. In contrast, the European crisis has seen only one restructuring as of the time of writing, in Greece. In the intervening episodes, there is a tendency for official financing to increase and emphasis on restructuring to fall." Different balances of forces, different management of defaults.

Financialization is important also for understanding the origin of public debt. In the BRE world, public debt grows because the government tries in vain to stimulate the economy. In doing so, it crowds out private assets that are replaced by public bonds. In reality, especially after 2008, we have seen another kind of replacement. Private debt had grown too much and produced financial instability, so it was socialized and became public. As Reinhart and Rogoff (2011) put it, "private debts become public debts after the crisis" (see also Praet 2011). So the origin of public debt should be traced back to the overall debt dynamic, where, in deregulated financial markets, private debt creation has completely outpaced public debt dynamics (Taylor 2012). When financial leverage grows too much, banks become unstable and "a fragile banking system can put at risk public finance" (Tagkalakis 2014). Therefore, there is a strong nexus between debt created in the financial sector and government debt (Acharya, Drechsler, and Schnabl 2012), with long-lasting consequences (Furceri and Zdzienicka 2012; see also Parrado-Martinèz, Partal Ureña, and Fernández-Aguado 2014). All in all, high levels of public debt in advanced economies are an important legacy of the global financial crisis (Ostry, Ghosh, and Espinoza 2015). In the dramatic events following the collapse of Lehman Brothers, the connection was obvious because governments were forced to use resources by the trillion to save the day, but the building up of the situation was decades in the making. For instance, tax cuts for the rich during George H. W. Bush's administration helped increase the debt-to-GDP ratio from 27 percent to 51 percent (Buiter 1993). Financial crises, not the welfare state, explain public deficit: "between two-thirds and three-quarters of the increased supply of longer-term Treasuries is explained by the dramatic growth in outstanding debt due to the large deficits associated with the Great Recession" (Greenwood et al. 2014).

The policy conclusions stemming from the BRE are dangerous exactly because they instruct policymakers to ignore private debt and financialization and connect the increase of public debt to the high levels of budget deficit. In fact, the "golden age" of the BRE discussion was 
the 1980s, when public debt, together with high inflation, was one of the main political concerns (Ricciuti 2003). However, in that period the reality on the ground was already different, as we can see in figure 3, which depicts federal government (FG) and domestic financial sector (DFS) debt as percentage of the total US debt. ${ }^{8}$

\section{Figure 3: Composition of US Debt}

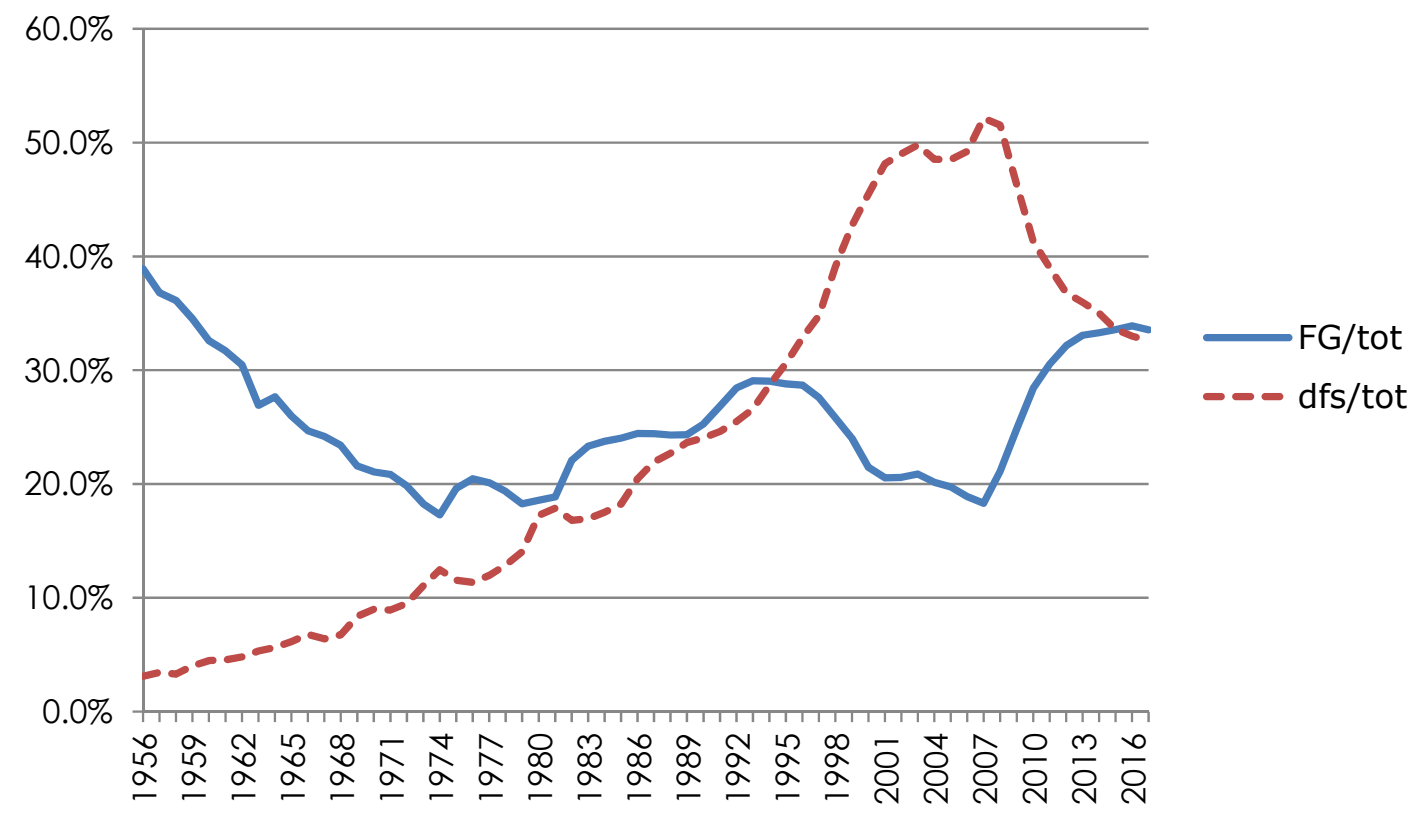

Source: Federal Reserve

The figure is quite clear. After the wars (the WWII and the Korean War), public debt shrank; then it started to grow again with the following war (Vietnam) until the 1990s, when it shrank again until the collapse of the banking system forced the US government to come to the rescue. Conversely, the role of the financial sector grew continuously until the 2008 crisis, then it deleveraged thanks to the public bailout. When the BRE debate started in the 1970s, public debt was under control, though financial debt was less and less so. The data were already clear in the 1980s and even before: the total debt was increasing fast, but public debt was not. Banking crises that trigger world recessions have been preceded by a rapid increase of private debts that, in their turn, "increase the likelihood of a sovereign default" (Reinhart and Rogoff 2011). What is striking is that international institutions knew long before 2008 that too much private debt is a danger. For instance, among the financial

\footnotetext{
${ }^{8}$ We use US data because the BRE debate was born in the US and because it was the most important economy on the planet in the period we are analyzing. For other countries the trend is similar, even if the historical sequence of events is unique for every nation.
} 
soundness indicators utilized by the IMF, many deal with private debt, but none deal with public debt (IMF 2006). The BRE contributed to letting economics forget these facts.

In ordinary economic analysis, connections between public and private debt are reduced to moral hazard and regulatory capture (Dowd 2008). The situation on the ground is, by far, more structural. The state cannot forget private debt (hence the situation of the banks) because, among many things, the collapse of the banking system means the collapse of the economy as a whole, public finance included. Once debt has grown too much, typically creating a financial bubble, there is no way it can be controlled without using public money (lending of last resort, outright nationalization of banks, fiscal stimulus, etc.). The origin of public debt from the 1980s on is, at the end of the day, financialization. This confirms the idea that default is a welcome blow to financialization itself, especially when the proportion of public debt held by banks and other financial firms is high.

There is one final point we must discuss when introducing the "how to" analysis is the role of central banks. If the BRE has not helped economic theory to deal with financialization, the same is true for its neoclassical critics. In particular, they insisted that an increase in public (but not private) debt pushes interest rates up. A recent restatement of the idea follows former Fed Chairman Ben Bernanke (2010): "Increasing levels of government debt relative to the size of the economy can lead to higher interest rates, which inhibit capital formation and productivity growth." In fact, one would expect that the dramatic increase in public debt levels in advanced economies could have "put considerable upward pressure on market yields" (Grande, Masciantonio, and Tiseno 2013). However, notwithstanding the massive increase, rates did not go up; quite the contrary: "Interest rates have never been so low for so long. ... Between December 2014 and end-May 2015, on average around \$2 trillion in global long-term sovereign debt... was trading at negative yields" (BIS 2015, 7). This is thanks to the central banks, as we have already noted. The total divergence between reality and theory is striking if we think that in the 1950s the role of central banks was usually acknowledged when discussing interest rates (for instance, Metzler [1951]) and it has not diminished ever since.

Central banks helped interest rates on public bonds to stay low and the government to sell whatever amount of debt they wished, but their role goes well beyond public debt placement. The general point is financial leverage. Higher leverage makes the economy more fragile. 
The most direct effect of this trend is the dynamic of the debt service ratio. If financial leverage increases, the debt service ratio goes up unless rates go down. In other terms, financial leverage decides the maximum feasible rate that avoids economic collapse; monetary policy can only follow. The fate of central banks is linked to financialization. That is why "room for manoeuvre in macroeconomic policy has been narrowing with every passing year" (BIS 2015, 21). Economic growth is also negatively influenced by financial leverage via the debt service burden (Juselius and Drehmann 2015).

Financialization explains the stance of monetary policy and also why central banks were forced to keep rates low even before the 2008 crisis. Mainstream economics did not link rates to financialization but only to inflation. However, after the crisis, inflation disappeared and economists were left with no sensible suggestions for central bank governors. Thus, while interest rates were sinking to historical lows, many economists, as we observed, predicted them to go up with government debt issuance or for inflation to skyrocket (Cochrane 2010). ${ }^{9}$ In other terms, they though that monetization automatically meant inflation because that's what happened from 1953 to 1974, but after 2008 this was not the case (Andolfatto 2018). The connection between monetization and inflation is by far more complex than was thought in the 50s, when it was thought that a mechanical rule that dictated the growth of monetary aggregates, like the Friedman rule, could help. Although central banks helped to keep rates down and monetization did not yield inflation, public debt exists and when it is sufficiently high it is prone to creating sudden waves of distrust (Calvo 1988). How it is possible to have such an outcome with "nonmonetary model[s] with one representative individual" is another story, and in many situations default can be the only way to solve the problem. Now we analyze the practical aspects of a default condition.

\footnotetext{
${ }^{9}$ Art Laffer (2009) has been one of the most vociferous of these predictors, stating: "We can expect rapidly rising prices and much, much higher interest rates over the next four or five years" (see Greenspan [2009] for similar concerns). The same assured conclusions were proposed for Italy (Lippi and Schivardi 2014): "There is little doubt that the huge increase in the money supply would lead to a proportional increase in prices." Many years have passed with no signs of strong inflation, while "interest rates have never been so low for so long" (BIS 2015).
} 


\subsection{Public Debt Default: Practical Issues...}

The main difference between the BRE framework and the real world is the impossibility of basing the analysis on the RAH: in the real world there is a distributional conflict and this is particularly clear in fiscal policy issues. The problem is that if the economy is not inhabited by representative agents, preferences are not aggregable; therefore what is an efficient outcome of a given policy is a matter of political opinion, not of scientific theorems. It is impossible to define what a Pareto optimum looks like when there is a struggle for the distribution of social wealth. This conclusion does not rule out discussions on fiscal policy (including the BRE), but it prevents any general conclusion. The situation on the ground is so different that the utility of a "theorem" is negligible. The historical and institutional analyses that we have quoted concerning several public defaults confirm that no general conclusions are in sight unless we put all countries and periods together to come out with an average, which is as useful as it would be for a zoologist to use the average weight of animals on planet Earth to understand their behavior. Bearing this in mind, we are going to deal with practical issues concerning the default, aware that we are dealing with them on a case-by-case basis.

As we said, fiscal policy is connected to distributional issues in a non-RAH world and this is also true for default. As Buiter (1993; emphasis in the original) pointed put: "Except in countries where the vast majority of the population lives on the edge of starvation, government debt default is always a policy choice." The choice is about who is called on to pay for the default. The more general (and obvious) conclusion that we can reach is that those who own public bonds are not keen on default. This is why the most important aspect in analyzing the outcome of the default is public debt distribution — both domestically (households, banks, central bank, etc.) and internationally. For instance, Reinhart and Rogoff (2013) point out that governments have more options with domestic debt (it can be sold forcefully to pension funds and banks, reduced by inflation, etc.), while a high proportion of external debt is considered a weakness. Distribution can also vary among generations. Typically, the older generation owns a larger part of the public debt. This can explain why the struggle between savers and debtors (Brunnermeier and Sannikov 2012) can also be seen as a generational conflict over taxes, inflation, welfare state goals, and so on. Moreover, it is not only the static distribution that is important, but how it changes over time and how rapidly it happens. For instance, if households retain public debt via pension funds, they cannot sell it as rapidly as an individual investor can. 
The nature of default is strongly connected to who is called on to pay it. A default can be a deliberate and preventive agreement and not an in extremis solution. A preemptive restructuring is better for market stability and is associated with lower output losses and shorter periods of market exclusion (Asonuma and Trebesch 2016). However, the default should be seen as necessary, because creditors are more inclined to forgive a default that looks like it is inevitable instead of a deliberate act (Grossman and van Huyck 1988). This could be linked to a reputational issue, as in signaling games: if the default was not inevitable, the defaulting government is considered "bad" by financial markets, although "reputational costs appear to be short-lived" (Li, Olivares-Caminal, and Panizza 2011). So the government should approach its creditors before it is too late, but not too early.

Another issue concerns how much to default. History shows that "default is always partial" (Arellano, Mateos-Planas, and Rios-Rull 2013), because no one pretends that the state should have no debt at all. Even the proausterity Maastricht Treaty considers a debt-to-GDP ratio below 60 percent acceptable. This means that if an EU state has a 120 percent ratio (quite high!), a 50 percent haircut is enough to reach the suitable proportion. Moreover, different haircuts can be envisaged for different bondholders, although this would create a rush to sell government bonds to those who benefited most from the haircut. In particular, the exclusion of small savers from public debt default has a long history and enjoys support from a wide political spectrum. Even the Bolshevik government in 1918 exempted small savers from the default on Tsarist debt (US GPO 1924, 206-7). For instance, to avoid arbitrage between bank deposits and public debt (the two most common ways for ordinary citizens to hold liquidity), it would be advisable to have a similar insurance framework in place. Depositors are protected by deposit insurance schemes until a given threshold, ${ }^{10}$ and the same threshold should be applied to public bonds. This different treatment makes sense on two main counts. First of all, public debt is normally strongly concentrated. Therefore a selective default would be good news in the fight against wealth concentration-a goal that even the IMF (2017) now considers paramount. This was also the stance of Smith ([1776] 1904). Secondly, although small savers do not hold a large part of public debt overall, the default can be a significant blow to their finances and they should be in some way shielded, as has happened for depositors since the 1930s.

\footnotetext{
${ }^{10}$ For Europe, see the European Banking Authority (EBA) website on the issue: https://eba.europa.eu/regulation-and-policy/recovery-and-resolution/deposit-guarantee-schemes-data.
} 
A final point we touch on regarding "how to default" is about its speed and secrecy. It is often suggested that the operation should be prepared quickly and maybe happen over a weekend to prevent financial turmoil. However, this is unrealistic to the extreme. First of all, the "default party" should promote the default based on its merits; secondly, it must win the election and then, having formed a government, it can proceed to the default. All these process takes months, but markets react in seconds. When the first polling research favorable to the "default party" comes out, markets would collapse, especially sovereign bond markets - well before the government announces the default, markets will price it in the public bonds. As for "secrecy," such an operation needs to count on hundreds of functionaries from various ministries, not only the central bank but also commercial banks and so on. It cannot realistically be kept secret for long. This shows, once again, that the default is a political battle over who is in charge: governments or financial markets. If the government does not have the courage to fight the markets, it is useless to propose policies that pretend to harm them. In another context, as the then-governor of the Bank of Italy Guido Carli observed: "Monetary policy is a crude instrument and those who wield it must not get impressed by the howls of those who suffer the wounds. If they cannot do it, it is better they lay it down." ${ }^{11}$ Similar conclusions can be drawn for other recipes, such as controls on capital movement that "are generally effective" (Nispi Landi and Schiavone 2018), a conclusion that the IMF now also acknowledges (Fernandez et al. 2016; Rafferty 2017) but that would cause enormous damage before being implemented, as the Greek case shows well. Governments and central banks must be determined to calm the market, as Mario Draghi did in 2012, using very clear words: "believe me, it will be enough" (ECB 2012a).

\section{4 ... and Their Effects}

We have already discussed the possible effects of the different solutions to public debt. Here we are going to deal only with the case of a default. Just as predefault situations can vary immensely, so will postdefault outcomes, depending on the aspects we described. For instance, restructuring (i.e., a partial default) has fewer negative effects (Das, Papaioannou, and Trebesch 2012). More generally, "hard defaults are associated with a much steeper drop in GDP" and it is better to act by consensus than to force creditors into a coerced default (Trebesch and Zabel 2017). However, analyses on growth effects are difficult because the

\footnotetext{
11 "La politica monetaria è uno strumento rozzo e chi lo brandisce non deve farsi prendere dal batticuore per lo sbraitare di chi ne subisce le ferite. Se non ha questa forza, è meglio che lo deponga" (Carli 1995, 144).
} 
direct effect could be low (especially when — as is normally the case - public debt does not contribute to economic growth or to public services). By far more important is the "animal spirits" effect, which is how the default can impact social and financial stability. This means that the default can help if it does not disrupt the banking system and does not harm too many people.

Social stability means that the default should have a wide political consensus. For instance, as we said, a financial shield for small savers is paramount. More generally, the default on public debt should signal a reorientation of economic policies toward more fairness and social justice. If it is only a way to reduce the burden for the state, it does not change much. The default government should pose the issue as a once-in-a-century chance to change direction. This will also help to prevent the dangerous idea that the default is not simply a one-time solution, but one that will be repeated in the future. In reality, unless government bonds are used to finance the welfare state by reducing the burden on public finances, the default today would make another default later less likely. It is also important for the state to focus its medium-term economic program on helping the generation that holds most of public debt (the elderly) because the default should not be received as a forced wealth redistribution to the youth. When the proportion of public debt held by foreign investors is huge, governments often use the tale of national pride against foreign exploitation, especially in emerging economies. At any rate, it is important to build a political consensus for the default because it also helps financial stability.

A default can unleash a panic situation on the markets. First of all, this can be due to the direct wealth effect of the default. Secondly, and more important, the problem is how animal spirits work. That is, to use Keynes's ([1936] 2018, 142) words “the mere consequence of upsetting the delicate balance of spontaneous optimism." However, this important observation must be put into context: How much optimism is there before the default? Often, if austerity policies hold sway, private investment levels are low because the economy is stagnating. How can the government bring private investors on board after the default? A few aspects are paramount. The first is assuring a flow of credit, even after the default. This means keeping the national banking system going (we will deal with it below). The second aspect is growth. Strong demand (linked to countercyclical policies) will create an environment for private investment. Animal spirits will improve rapidly when it becomes 
clear that default is not an end in itself, but the beginning of a different policy framework. Without this change, the default is still desirable, but far from enough.

Thirdly, when financial intermediaries hold a significant part of public debt, the default puts their solvency at risk because public bonds are liquid assets, entail low capital requirements, and are an important part of what is available for monetary policy operations. The health of the banks is a necessary prerequisite for avoiding a credit crunch (which is what connects a sovereign debt crisis to a recession) and a subsequent collapse in investment (Del Giovane, Nobili, and Signoretti 2013). Technically, the 2008 crisis demonstrated how many smart tools are at our disposal for preventing the collapse of the banking system, but also that there are many taboos that can be easily overcome if needed. For instance, however unthinkable a decade ago, the partial nationalization of the financial system has been fairly common, even in traditionally promarket countries. The state can help the banks via a direct recapitalization, sharing risks on financial portfolios, lending of last resort, and so on. The 2008 example is important in two aspects. The positive example is that, as national banking systems were rescued using public money, they were somewhat forced to focus on domestic credit. In a situation of public debt default this is not a negative outcome, and it is also better in terms of leveling the playing field on the international markets (this is also true for the eurozone, because banks rescued with public money will mainly not compete in international markets, but will retrench to their traditional shores [EC 2017]). The negative side is that public money should help to rebalance the relationship between finance and politics, but this is not what happened after 2008. Trillions of euros (or dollars) of public money have been used, but the financial system (especially the big banks) has even more power.

We do not go deeper into different technical alternatives because markets primarily will not react to these details, but rather to the political and economic scenario that the default would open. Markets hate uncertainty. A default that made clear not only who pays but also the medium- and long-term benefits would be a blow to financial markets, though not necessarily a heavy one. After all, risk is the name of the game and even huge losses are the norm in financial markets. Political will is the vital aspect of the issue. The core aspect of the default is exactly how it can spur growth and this depends crucially on people feeling that the government is in control and can be trusted. As shown by many historical examples, if the default puts the national economy on a long-term path of growth, losses will be rapidly forgotten (Reinhart and Rogoff 2009). The real danger is created by domino defaults; 
therefore, although paradoxical, it is better if the default comes during a period of international economic growth, as it would be the materialization of an idiosyncratic risk, and this is something that markets deal with pretty well.

To sum up our point, political issues are the most important. For instance, the dimension of public debt is an important element in predicting the havoc on the markets provoked by its default, but political governance is always the main driver, as was clear in 2012-13, when the Cypriot financial crisis produced turmoil in the eurozone market although the weight of its economy is negligible vis-à-vis the eurozone GDP (IMF 2013b). Bigger defaults of local US administrations (for instance Detroit) provoked much less gyration in the market, pointing to another demonstration that quantity matters, but politics matters even more.

A last observation on the relationship between government and the markets. Animal spirits are not automatically good, nor should they be "courted" at all costs. Wild finance is something that the world economy has paid dearly for in the last few decades. Pessimistic financial animal spirits are not necessarily a bad outcome, provided that governments are in the driver's seat of world economy, because if not, uncertainty will grow and economic stagnation will grow along with it. Considering that markets are not efficient nor do investors necessarily know what they are doing, governments often impose a strategy that is not appreciated by financial markets at first, but in due time, if it spurs an era of higher growth, it is endorsed by animal spirits, too. What is important is to stop the immediate panic, as policymakers did in 2008 and in other episodes of financial distress.

\section{THE ITALIAN SCENARIO}

We are now going to move to looking at Italy without pretending to give a thorough analysis of the situation. To do so, a whole series of econometric estimates, as well as considerations on juridical, political, and accounting rules, would be needed and this is not the aim of this work. We turn to Italy as an interesting case, especially because its public debt has been historically high and has also grown considerably since the 2008 crisis, so it can be considered a good candidate for default. We still try, however, to draw more general conclusions. Let us start from the specificities of Italy's EU membership. 


\subsection{The European Conundrum}

We must first assess what solutions are unavailable inside the EU framework. Of the alternatives we examined in section 3.2:

- inflation and deflation are no longer possible at a national level;

- the ECB would not be keen on a "Japanese" degree of monetization, although after 2012, a moderate monetization was allowed;

- strong countercyclical policies are ruled out (on the overall functioning of the "fiscal compact" see ECB [2012]); and

- financial repression cannot be implemented, even on a continental scale, given that most banking regulation is international (Basel Committee, etc.).

All in all, default is the only solution left for a eurozone country and, per se, it would not be the end of the euro, as Greece has shown (Paris and Wiplosz 2013). Lacking other ways to deal with the eurozone crisis, projects that propose how to tackle the issue of national public debts are multiplying. For instance, there are proposals for a European redemption fund that would hold a part of national public debt (Parello and Visco 2012; Bank of Italy 2018a, 35), for of provisions for automatic restructuring (Committeri and Tommasino 2018), for an automatic debt-to-equity swap (Mody 2013) or less-automatic proposals like a debt buyback (Corsetti et al. 2015), and, finally, proposals for the creation of a common euro area debt, the so called "blue bonds" (Delpla and von Weizsacker 2010"12; see also EU DGIP [2011] and Merler and Pisani-Ferry [2012]), or a euro Treasury (Bibow 2013). Recently EU institutions have put up similar proposals in the form of European sovereign bond-backed securities (for a critical assessment, see Tonveronachi [2018]). All of these proposals are summed up in Cioffi et al. (2019), with an additional original proposal for a European redemption fund.

These ideas all point in the right direction. However, they are politically unfeasible, just like their predecessors, such as European safe bonds (Brunnermeier 2016) and the mutualization of debt (Varoufakis, Holland, and Galbraith 2013), especially "in the interests of the working classes and the social majority" (Sotiropoulos, Milios, and Lapatsioras 2014). The problem is that in order to convince strong countries that mutualization is in their interest, these proposals come with such strong conditionalities that they are tantamount to keeping on with

\footnotetext{
12 The idea is to pool up "blue bonds" (i.e., public debt up to the Maastricht threshold of 60 percent GDP/debt ratio) as joint senior sovereign debt, leaving the rest ("red bonds") as national and junior debt.
} 
austerity (Minenna, Boi, and Verzella 2016, ch 10). The same holds true for tapping the European Financial Stability Facility or the European Stability Mechanism (ESM). The conclusive demonstration of the political unfeasibility of these proposals is that eurozone countries were not able to even agree on a common deposit insurance scheme, which is by far less challenging than public debt mutualization (Panetta 2018). We can safely assume that all these proposals are not likely to produce anything. As Tonveronachi (2016) has aptly concluded: "significant mutualization of European sovereign risks will have to wait for several decades, if it ever becomes reality." Solutions can only be found on a national level, and this means defaulting now and issuing different national public bonds tomorrow.

A last point is in order on financialization and the eurozone. The European economic policy framework is fiercely against state intervention, or so it seemed before 2008 . Then we learned that, to paraphrase Orwell, all Europeans are equal, but some Europeans are more equal than others. In particular, banks are by far more equal, i.e., they deserve to be bailed out with public money. A striking difference has been made between financial and public debt. Banks assets have been mutualized, ${ }^{13}$ but public debts have not. This was not enough, so after the 2011-12 euro crisis, EU institutions decided to make public debt management less and less flexible with collective action clauses that restrict options for the government. Even now, the proportion of public debt held by the eurosystem is sufficient for preventing any debt redenomination (Minenna, Boi, and Verzella 2016, 355), while the banks have been saved directly and indirectly in every possible way. Bailing out banks was inevitable to keep the European economy going; the point is what kind of bailout and to what end. Eventually, it was a quintessential case of "socialism for the rich" (Reich 2019), where eurozone institutions care for the banks' destiny while the Greek people and many others are left to fend for themselves. To rebalance the situation, European governments should have started to make the financial system pay for its bail-in after 2008 and default is the surest and quickest way to do it. After all, it has been noted that "making government debts defaultable was the intention of eurozone architects" (Terzi 2014). So let it be!

\footnotetext{
${ }^{13}$ For instance, saving European banks that bought most of the Greek public debt and using the long-term refinancing operations (LTRO) that gave around $€ 1$ trillion to failing banks saved the European banking system in 2011-12 (Minenna 2014), but also relaxed the collateral quality requirements (Dewatripont, Rochet, and Tirole 2010, 37).
} 


\subsection{How an Italian Default Could Look}

We start by analyzing the data on the distribution of Italian public bonds. Table 1 shows the situation at the end of 2017.

Table 1: Italian Public Bond Distribution at the End of 2017

\begin{tabular}{|c|c|c|c|c|c|c|c|c|c|c|}
\hline & $\mathrm{H}$ & NFC & $\mathrm{CB}$ & MFI & OFI & IC & $\mathrm{PF}$ & $\mathrm{MF}$ & RW & total $(\mathrm{C})$ \\
\hline public debt (A) & 122,171 & 52,811 & 404,950 & 329,752 & 34,928 & 322,008 & 9,330 & 55,201 & 754,440 & $2,085,591$ \\
\hline total assets (B) & $4,406,694$ & $1,816,246$ & 934,906 & $3,734,774$ & 726,494 & 849,344 & 86,199 & 277,449 & $2,649,242$ & \\
\hline $\mathrm{A} / \mathrm{B}$ & $2.8 \%$ & $2.9 \%$ & $43.3 \%$ & $8.8 \%$ & $4.8 \%$ & $37.9 \%$ & $10.8 \%$ & $19.9 \%$ & $28.5 \%$ & \\
\hline $\mathrm{A} / \mathrm{C}$ & $5.7 \%$ & $2.5 \%$ & $19.0 \%$ & $15.5 \%$ & $1.6 \%$ & $15.1 \%$ & $0.4 \%$ & $2.6 \%$ & $35.4 \%$ & \\
\hline
\end{tabular}

Source: Bank of Italy (2018b, table 3$)$.

Notes: Figures in $€$ million. H: households; RW: rest of the world; NFC: nonfinancial corporation; PF: pension funds; IC: insurance companies; CB: central banks of the Eurosystem; MF: nonmonetary mutual funds; MFI: monetary financial institutions; OFI: other financial institutions. We excluded minor bondholders (together they make up less than 2 percent of the total amount).

Table 1 gives a number of interesting insights. First, public debt held by the eurosystem is relevant (around 20 percent), having tripled since 2015, when the Public Sector Purchase Programme started (monetization is well under way!). The percentage held by foreigners is around one-third. Households hold a small part of the public debt (less than 6 percent) and public bonds are a small part of their wealth (less than 3 percent). This does not change much if we also consider indirect ownership via institutional investors (the total goes to around $€ 190$ billion, even if we attribute all the indirect ownership to households). Industrial or commercial firms do not hold much public debt either. On the contrary, banks and insurance companies hold a significant proportion of the public debt (around 30 percent together) and it is an important part of their assets. These data remind us that, as we have already observed, in order to default smoothly, a country should have a plan for avoiding losses that are too big for the financial system (financial stability) and for households whose wealth is low and concentrated in public bonds (political appetite for the default).

Of course, the distribution of public debt changes, even rapidly. For instance, in the 1970s households were holding around the same proportion as in 2017, but this increased to almost half of the total in the 1980s, while the rest of the world did not hold Italian public debt in the 1970s and 1980s. As for monetization, in 1975 the central bank held more than half of the public debt, while in 1985 it was 13 percent; now, as we have seen, it is around 20 percent. We synthesize the last two decades in figure 4. 
Figure 4: Sectoral Holdings of Public Debt in Italy

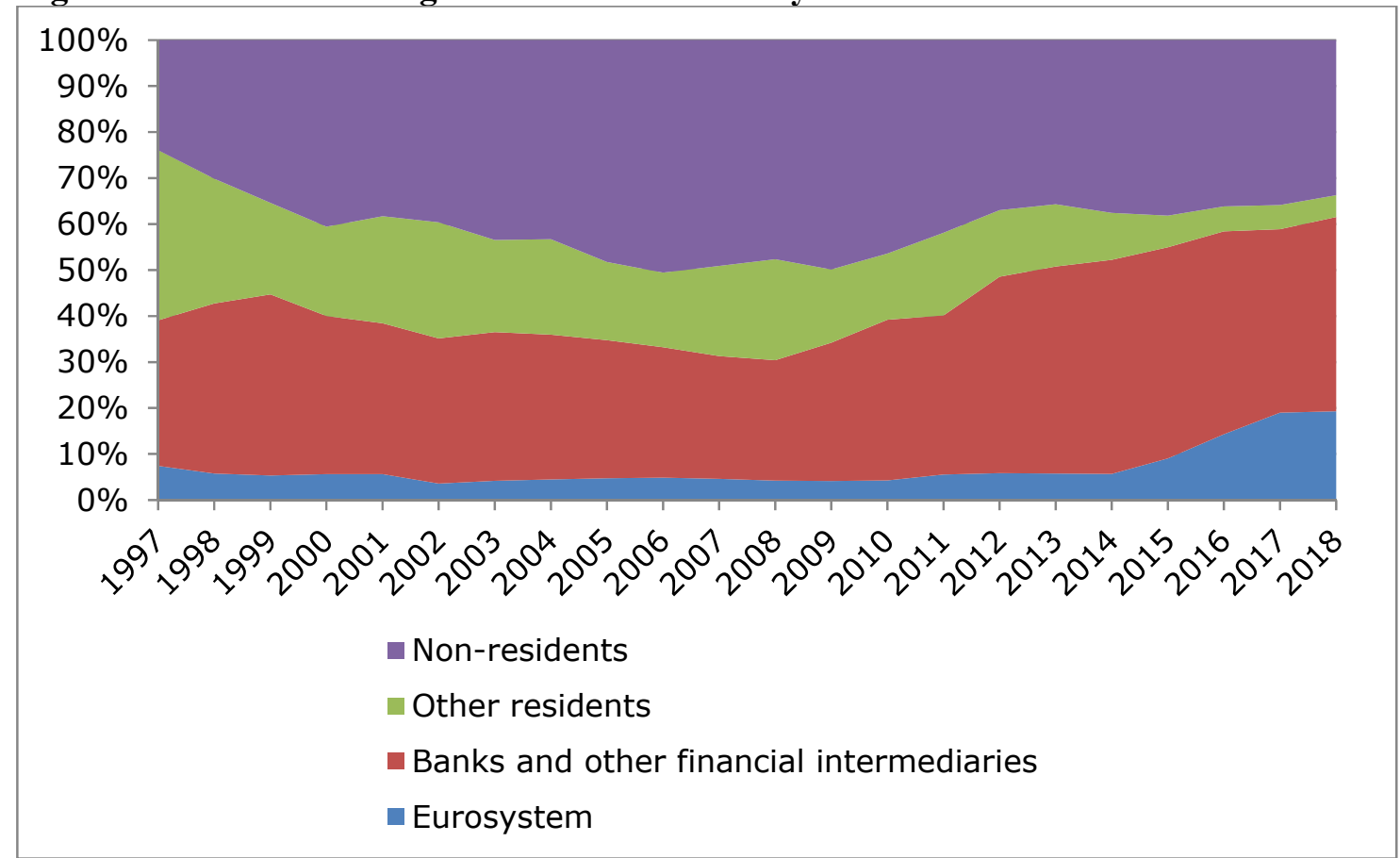

Source: Bruegel.org (data at the end of the year except 2018, June)

Data show that the percentage of Italian public debt held (at least directly) by households has collapsed, and also that after the 2012 sovereign crisis, international investors' appetite for Italian public bonds has diminished. As we noted, public debt distribution is important because it dictates who will be called on to pay for the default. Today in Italy, the problem would be concentrated in the financial system. For instance, at the end of 2017, Italian banks had their own funds for around $€ 240$ billion and $€ 330$ billion of public bonds. Even a partial default on these assets would sink them.

Debt distribution also sheds light on the possible effects on growth. Households, for instance, hold less than $€ 200$ billion in Italian public bonds, so the wealth effect of reducing the connected interests, say by half, would be negligible. Moreover, after the bail-in approach came into force for EU banks, it is not so peculiar for bondholders to be called to pay for a default (in a bank default even depositors are asked, under certain conditions, to contribute). ${ }^{14}$ As for economic growth, we observe that public debt is completely detached from Italian public services and it is only a drain of resources. For instance, from 2012 to 2017 (very difficult years for Italian economy), the primary surplus was never less than 1.5

\footnotetext{
${ }^{14}$ See the EU website on Bank Recovery and Resolution Directive for an overview of the new resolution framework for banks (https://ec.europa.eu/info/law/bank-recovery-and-resolution-directive-2014-59-eu_en).
} 
percent and, since the crisis, only in 2009 was there a budget deficit ( 0.8 percent in 2009); in the meantime, state bondholders have received $€ 737$ billion.

Due to the holding composition of the public debt we described, the resources needed to tame the turmoil in the banking system after a default would be conspicuous, although in line with what happened in 2008. ${ }^{15}$ Moreover, these resources would amount to what bondholders normally receive in under than a decade, but, hopefully, with a lot more traction on national economy than was the case with quantative easing $(\mathrm{QE})$, which did not help the country as a whole very much.

Another important point coming from the data is the "rest of the world" part of public debt. The issue here is the following: Does Italy risk being excluded from international markets and, also, would foreign banks leave the country? The first question is less relevant because Italy would not need immediate access to international capital markets and historical experience shows that the market's memory does not last more than 4-5 years. The second question is by far more important because branches and subsidiaries of foreign banks are very active in Italy, especially as a primary dealer of public debt, as well as in the investment banking business. ${ }^{16}$ In the immediate aftermath of the default it is important that the government treat foreign banks just like domestic banks so that their relative competitive situation would not change. We can expect an immediate reduction in the appetite for Italian financial assets (including credit and corporate bonds), but in the medium term the default can help economic growth, thus reducing the probability of default by Italian clients, and foreign banks will be more interested in operating in Italy.

A last issue that is also important for the effects of the event is "how much" to default. Given that an econometric simulation would require a whole series of shaky hypotheses, we prefer to use an institutional threshold. As the Maastricht Treaty has introduced the 60 percent government-debt-to-GDP threshold, this can also be a guide to the appropriate haircut. For

\footnotetext{
${ }^{15}$ It is difficult to estimate the crisis costs because it means putting together very different kinds of interventions. However, any calculation is impressive. Estimates go from \$6 to \$14 trillion (Atkinson, Luttrell, and Rosenblum 2013) "or almost a quarter of global GDP. It dwarfs any previous state support of the banking system" (Haldane 2009) or also "between USD 60 trillion and USD 200 trillion" (Dombret 2013). In the US, resources put at Wall Street's disposal were around \$24 trillion or 150 percent of the country’s GDP (Johnson and Kwak 2010).

${ }^{16}$ Even without considering Italian banks owned by foreign groups, foreign branches hold, for instance, a market share of 80 percent in syndicated loans, 25 percent in the leasing market, 19 percent in the factoring market, and 45 percent in the consumer credit market (AIBE 2017).
} 
the present Italian situation this would mean a reduction of around 70 percentage points to bring the ratio below 60 percent. For every $€ 100$ of government bonds, $€ 45$ would be paid back year after year. For instance, this would cost the banking system around $€ 30$ billion a year (without taking into account international financial reporting standards rules) against almost $€ 14$ billion of profits in 2017.

\section{ON PUBLIC INVESTMENT AND FUNCTIONAL FINANCE}

"The most terrifying words in the English language are: I'm from the government and I'm here to help.” (Ronald Reagan, quoted in Phillips Erb 2011)

Behind the BRE there is the political position synthesized in President Reagan's quotation above. In this context, by definition, public investments are useless. (Re)born in the 1970s, this theoretical and political stance was still strong in 2008, as we can see in the debate on the famous 90 percent debt-to-GDP threshold by Reinhart and Rogoff (Herndon, Ash, and Pollin 2013). Only after the crisis has it been possible to admit that the world is dying of too much finance, not too much state (Arcand, Berkes, and Panizza 2012). Moreover, many studies have found that private debt is more dangerous than public debt when the country falls into a recession (Batini, Melina, and Villa 2018).

The success of laissez-faire theories, like the BRE, had practical consequences in the making of economic policies, especially in Europe. In particular, the Maastricht Treaty framework deals with public debt, but not with private debt. ${ }^{17}$ Then, apparently all of a sudden, the European financial system was shattered by the 2008 crisis and public debt on the continent increased by almost 20 percent due to the bank bailout (Ejsing and Lemke 2011; EC 2011; Tagkalakis 2014). After decades spent squeezing the welfare state and helping wealth and income distribution upward (for instance, via financial deregulation [Korinek and Kreamer 2013]), governments in the EU, the US, and elsewhere used public money to the tune of trillions of dollars to save big banks (Haldane 2009). However, the lesson was not clear enough to push European institutions to change their path. The policies undertaken after the crisis (QEs, banking union, fiscal compact, and so on) are a restatement of the BRE

${ }^{17}$ As is well-known, two out of five criteria of the Maastricht Treaty are about public debt, but none are about debt as a whole; seehttp://ec.europa.eu/economy_finance/euro/adoption/who_can_join/index_en.htm. 
outlook - that is, private debts are good and state intervention (and debt) is ineffective. This means increasing critiques and disillusionments about the European Union project, as Brexit, inter alia, has shown.

In the BRE context, public investment cannot revamp the economy, no matter how it is implemented (for instance, Barro and Redlick [2011]). There is no such thing as a productive public investment. This is contradictory, because the BRE states that all bonds are the same. As Richardson (2015) noted: "in the discussion here all debt is treated equally or, what amounts to much the same thing, it is assumed government and other debt are close substitutes." In fact, economists that accept the BRE give examples of productive public investment (Bailey 1993) and, in a neoclassical analysis of liquidity risk, public money can buy capital goods (Diamond 1965). It is interesting that after the 2008 crisis, Barro himself proposed a similar idea. Once again attacking the use of public deficit to save the day, Barro (2009) observed: "the value of the project (counting, say, the whole flow of future benefits from a bridge or a road) has to justify the social cost. I think this perspective, not the supposed macroeconomic benefits from fiscal stimulus, is the right one to apply to the many new and expanded government programs that we are likely to see this year and next." In other terms, it is the composition of investment that matters; therefore, the idea that cutting public finances is automatically good or public debt is automatically bad is misplaced. In a 1974 paper, Barro explains that due to imperfect private capital markets, "the relevant discount rate for tax liabilities will be higher than that for interest payments," but, if the 2009 Barro is right and what counts is the specific "value of the project," the outcome of public investment can vary considerably. Therefore, the difference in the discount rate is not linked to the nature of the issuer but to the difference in the economic structure induced by public investment. The net wealth coming from government bonds will depend on their specific economic function, not on them being public.

All things considered, we have two conflicting parts of a theory and we should decide which one is viable: the theoretical side that states that debt is debt, whether public or private, and as long as it is used productively it increases social wealth, or the political side that states that public bonds are always bad. We think that Barro (2009) is right: composition matters. This can explain why the effectiveness of the BRE results is different among countries depending on the specific budget components (Röhn 2010). It is not the same if the state mobilizes resources to bailout banks or to assure full employment (Tcherneva 2012). In 
particular, well-managed public investment can remold the landscape of the economy, raising long-term potential output, as even the IMF acknowledged (Fiebiger and Lavoie 2017). The discussion is not about numbers anymore (as in the BRE framework), but about projects and accountability - it is not the quantity but the quality of state expenses (Visco 2017). This conclusion can also be seen as a warning against the idea that increasing public investment is automatically a good long-term proposal and that stagnation comes from European-imposed austerity. The more general role of public investment as a technological incubator is coming back on the agenda (Mazzucato 2013). Data confirm that public spending on innovation can have a significant impact on economic growth (Hanusch, Chakrarborty, and Khurana 2017). At least on these issues, the 2008 crisis has had a positive effect on theoretical debates. A long-term project to reshape the state of public infrastructure and public services (such as healthcare and eduction) can significantly raise overall productivity (for the US, see EPI [2017]; for the eurozone, see ECB [2016]). It is also worth observing that a fall in public investment also forces private investment down, as shown in figures 5 and 6.

\section{Figure 5: Public Investment as a Percentage of GDP}

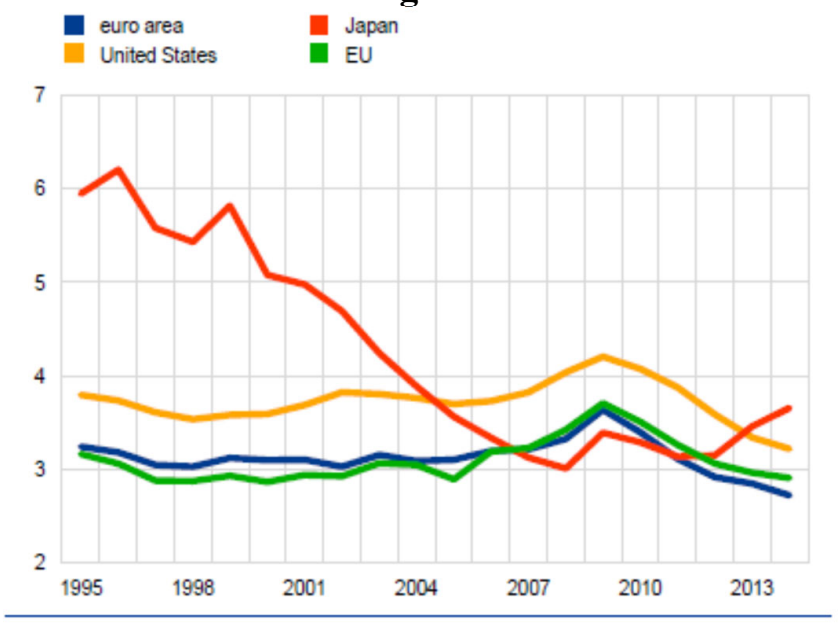

Source: ECB $(2016,78)$ 
Figure 6: Private Investment as a Percentage of GDP

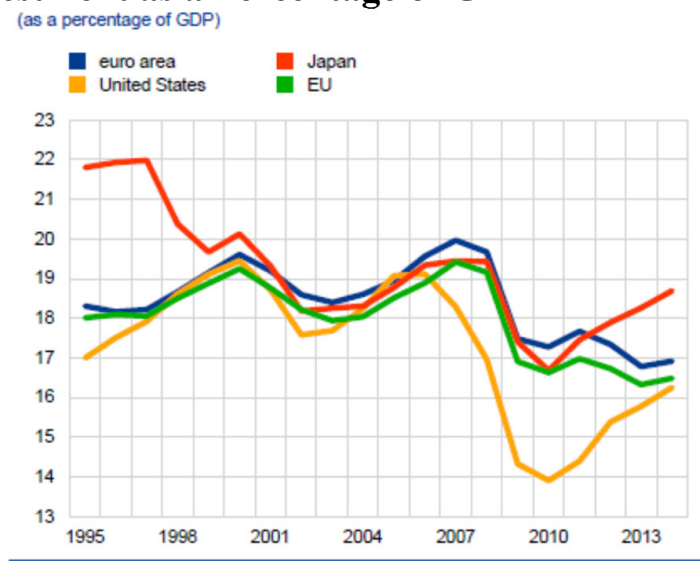

Source: ECB $(2016,78)$

The idea that public investment and debt always and perfectly crowd out private investment does not hold up to historical scrutiny, but this does not mean that in a given situation this cannot happen. For instance, in Italy this was the case in the 1970s and the 1980s because public finances were so distressed that savings were more or less forcefully channeled to fund the state instead of the private sector (De Rosa 1997, 821). Moreover, in Italy (and elsewhere) we have abundant proof that public money can be wasted. Defaulting on the present public debt and a comprehensive plan of public investment can work only if this is done efficiently. ${ }^{18}$ The possibility that public money can be wasted should not be an excuse to renounce public investment, just like failures in banking supervision are not a good reason to scrap it altogether. On the contrary, it is a reason to strengthen and improve it. The same holds true for the use of public money.

\section{CONCLUSIONS: HOW TO USE THE BRE TO SAVE THE WORLD}

In this work we have analyzed the theoretical as well as the practical implications of the BRE. From a methodological point of view, the fact that these two issues can be treated separately is a significant elucidation of the shortcomings of modern economics. If theoretical assumptions and the real world are hardly connected, what is the point in seeking policy advice from a theory so detached from the reality it should explain?

\footnotetext{
${ }^{18}$ On the issue of how to develop an effective control system for public investment, see Mastromatteo and Esposito (2015, sec. 10) and Mastromatteo and Esposito (2017a).
} 
Our main theoretical conclusion is that, given that the BRE is based on a world inhabited by representative agents, it cannot take into account financialization and more generally in this framework it is useless to speak about finance, debt, banks, money, government, income distribution, or wealth inequality because, by construction, they are nonexistent problems. Now, in the present situation, is it advisable to retain a theory that cannot even assume the existence of these issues? Either we renounce the RAH or we renounce speaking about finance, debt, and bonds - which would be paradoxical, given that the BRE was introduced to explain the influence of government debt on economic growth. The RAH prevents economic analysis from understanding the role of finance (and, hence, financialization) on growth and it has had enormous consequences on what central banks and governments did until the 2008 crisis struck, as well as what they are doing now, especially in Europe. As Carsten Detken (1999) noted, the BRE rationalized austerity as if its assumptions were effective for depicting the realities of the European economy. This is the part of the BRE that is less useful for understanding the modern economy because it has nothing useful to say on a world not based on the representative agent. This is true more generally for the existing economic policy paradigm (Bayoumi et al. 2014) and for dynamic stochastic general equilibrium models used by central banks to set their policies (Vines and Willis 2018; Romer 2016).

We think the task of revamping the world economy requires a new approach. Finance and banks should be put at the core of economic analysis and this means talking about distributional issues, as well as creditors and debtors. Why is economic growth more and more dependent on debt? What is the link between debt creation and financial fragility? These questions allow us to rediscover Hyman Minsky's suggestions on financial fragility (1982) and the role of government in preventing financial collapse. In particular, Minsky explained that the size of government intervention should depend on financial leverage: the higher the leverage, the riskier the situation, hence the stronger the need for public intervention. The 2008 crisis completely vindicated this approach.

In fact, financialization means bigger banks and financial markets and a higher level of leverage; therefore there is a structural need for more public intervention. In this sense, the BRE could be an interesting way to look at debt—public or private alike, since they all end up as a problem to the taxpayers. Unfortunately, the logic of the BRE is very different. It is a theoretical pretext for burying public pensions, public hospitals, public schools, and so on 
while financial markets are allowed to grow wild. Its theoretical assumptions do not allow an interesting analysis of debt dynamics. On the contrary, if we leave aside its more politically oriented hypotheses, the BRE can show us that the nature of debt is not decisive. Debts are debts and private debts easily end as public problems. What is important for predicting the dynamics of the system in terms of financial stability, economic growth, etc. is the overall leverage, not only its public component. BRE cum financialization can help to completely change the framework used for assessing economic policies: if a policy is not able to reduce the overall leverage, it can only delay problems but cannot solve them. This new framework can explain why QE succeeded in saving banks but not in putting the economy back on a growth path. On the contrary, the BRE literature forgot private debt, ${ }^{19}$ while if it had explored the equivalence between public and private bonds it would have found that this is due to structural changes in the relationship between the state and large corporations, what Oscar Jordà, Moritz Schularick, and Alan Taylor (2016) call "shifts in foundational macroeconomic relationship."

On the theoretical side, the other important aspect that BRE cum financialization allows one to understand is the meaning of financial wealth. When and how can a debt be wealth? In a world without the representative agent, private wealth is not automatically social wealth and only the stability of markets can confirm it as social wealth. Therefore, financial asset prices are significant only inasmuch as the state ensures sufficient production of a public good called market stability. This could completely change many assumptions and conclusions of finance theory. Taken together, our two theoretical conclusions mean that the point is not the nature of debt — public versus private - the point is micro versus macro. Bonds are net (social) wealth only if markets are stable because of effective macroeconomic policies. This is the secret of the financial wealth of the nations.

The connection between financialization and financial instability also highlights a methodological issue. Since 2008, there has been a wide discussion on so called "black swan events" (Taleb 2007; Barro and Jin 2016). These are episodes that are unpredictable but that should be in some way considered in shaping public policies and risk-management strategies. The problem with this explanation is that public default is not a black swan unless we recognize the existence of enormous gaggles of black swans. We are reminded that

\footnotetext{
${ }^{19}$ See for instance John Seater's (1993) "long journey" on the issue (a thorough survey on the equivalence literature) where the dynamic of private debt is not even mentioned.
} 
hundreds of such events have occurred over the last few centuries. Even more important, financialization yields a higher level of financial leverage for banks, states, households, and firms, and, hence, a more fragile financial environment. Financialization means that black swans are multiplying year after year. This brings us to the methodological question: What does a prediction look like in economics? Without extending famous epistemological quarrels on that topic, we simply propose the basic idea that prediction cannot mean an exact forecast of the day or the financial asset that starts the crisis (because it would prevent the crisis in the first place). Such a prediction cannot exist, but economists can detect the main trends of the financial and real markets to try to assess their consequences. If the link between financialization and instability had been well explained in the 2000 s, policymakers would have been ready for the crisis.

On the practical side, this brings us to the role of the state vis-à-vis financial markets. We think that Minsky (1982) was right to point out that the quantity of state intervention is decided by the level of financialization. The more financialized is the world (i.e., the more indebted and financially fragile), the more financial wealth depends on the state. Given that public or private debt alike can end up as a problem for taxpayers, financial assets are worth what financial stability and, hence, the policymakers decides them to be. This explains why the amount of money spent by the United States and the eurozone after 2008 was by far the biggest public economic intervention of modern times, dwarfing WWII and the Great Depression. If how much is dictated by the size of financial markets, how is debatable: the specific composition of public intervention should be thoroughly discussed because it matters, as even Barro suggested. Public investment must be aimed at raising productivity and growth, as well as helping the real economy to expand to rebalance the situation. This is a definite improvement on the original BRE. If how public money is spent does make a difference, then it makes sense to discuss an alternative strategy to austerity based on the active role of the state, rediscovering the fact that public investments are decisive in spurring world growth as, among others, both the IMF (2015) and the German Ministry for Economic Affairs and Energy have acknowledged (Janssen 2016). In fact, as stressed by Mariana Mazzucato (2013), public investment is able to create new economic sectors from scratch, allowing for breakthrough innovation and stimulating bandwagoning by private firms, an approach based on long-term perspectives that cannot be adopted by financial operators. In the present situation of stagnation or feeble growth on a global scale, the state must take a leading role in starting a new wave of industrial and technological revolutions, going far 
beyond tax rebates for investment. What is at stake is not an increase of investment in this or that sector, but the creation of entire industries.

We explained in this paper that financialization means a less favorable balance of forces between the state and financial markets. This can also explain the differences between the postcrisis policies in the 1930s and the policies of the 2000s. While Roosevelt succeeded in taming finance for decades, Obama was not able to change much. This is graphically depicted by Wall Street indexes: after the 1929 crash, the Dow Jones needed almost three decades to regain that peak, while after 2008 a few years were enough. To use a wildlife metaphor, Roosevelt had to control a tiger cub, while Obama was trying to discipline an adult tiger. When we discuss different solutions to high levels of public debt (but the same holds true for banking regulation and other issues), we should take into account this metaphor: How we can control a big hungry tiger in a way that is both effective but does not make the tiger feel backed into a corner? A cage (that is, comprehensive long-term financial repression) would be ideal, but not necessarily at hand. Significant market mayhem helps make the world aware of how dangerous the tiger is; this is the good news after 2008, although the tiger is still at large.

This new situation, where mainstream conclusions have resoundingly failed, has also encouraged a revival of old debates on public finance. In particular, there is a growing debate on "functional finance" that started even before the crisis and it is now widespread (Mastromatteo and Esposito 2015; see also the references). The term functional finance was coined by Abba Lerner (1943), reflecting the growing awareness of the policy implications of Keynes's General Theory. Lerner believed that the public budget should not only fulfil its traditional allocative tasks but should also address the problem of the stabilization of the economy. According to this theory, public finance should be functional for the long-term development of the system. Fiscal policy is needed because financialization, even before the collapse of a bubble, increases inequality and poverty, so that aggregate demand stabilization is needed to simply get the things going. And after a crisis, functional finance is even more needed to cure mass unemployment. Using the weight of the state in the economy, this approach is aimed at reducing financial leverage and rebalancing income and wealth. Lerner's proposal was to give the state the goal of full employment, using every tool at its disposal to this end (this is the functionality of finance). In the BRE world, this goal is superfluous because of Say's law. 
What is striking, however, is that Lerner's functional finance is in line with the BRE as far as the size issue is concerned. Lerner (1943) pointed out: "the absolute size of the national debt does not matter at all, and that however large the interest payments that have to be made, these do not constitute any burden upon society as a whole." As in the BRE framework, in the functional finance world, if the government-issued public debt does not create net wealth but does not destroy it, overall wealth is the same: "The greater the national debt the greater is the quantity of private wealth. The reason for this is simply that for every dollar of debt owed by the government there is a private creditor who owns the government obligations" (Ülgen 2014). As we have seen, modern analysis, for instance the stock-flow consistent approach, reaches the same conclusion (Tcherneva 2008). It is interesting that such different approaches reach the same conclusion regarding public debt as net wealth, the original BRE issue, because they link private investors' wealth to the role of public authorities as providers of aggregate demand and liquidity. However, we are aware that the BRE is based on Say's law, while the possibility of public debt being wealth is based on John Law's observations.

The more politically controversial point concerns the best strategy for dealing with public debt. We showed that, although it is not generally understood, under the BRE assumptions, default is always the best solution for a government and it has no negative effects whatsoever. We are aware of the fact that BRE assumptions are so extreme that we cannot sic et simpliciter use this conclusion in the real world. The not-so-paradoxical fact that private banks have often proposed (if not imposed) default for governments is a clue that the BRE's assumptions are invalid and that default can be a something that citizens will blame on politicians and bureaucrats, no matter what the proximate causes are (including a banking system bailout). In fact, the consequences of a default can be very painful for voters, even if they do not hold much public debt. For sure, frightened policymakers are not suitable for managing a default because they will give the markets all kinds of wrong signals while (we repeat once again) the effects of a default depend on its political management and, to a lesser extent, the technical details that stem from political decisions. In this framework, default represents a glaring symbol of a different course in policymaking based on a long-term public investment program, not on the immediate interests of the financial system. We are not advocating "strong governments," because they are normally strong with the wrong targets and very soft with the financial system. We are suggesting that the government should be able to seek the best policies for the economy as a whole in the long run. Moreover, due to the failures of austerity and the lack of viable alternatives, eurozone 
countries risk arming "strong governments" with very dangerous programs, pointing to a conflictual end of the European Union project.

On the topic of motivations for default, outside of the BRE hypotheses, we have explained that it is a way to rebalance the forces between the government and the markets. We acknowledge that other policies can have the same effect and one we have proposed is a world-sized cap for banks to force a break-up of the biggest financial conglomerates (Mastromatteo and Esposito 2016). The problem is that these measures are not as quick as a default. For instance, for the world-sized cap for banks to be effective it should be international, while a default can be imposed on a national level. While an international agreement on the world-sized cap would take years, a default can be decided on in weeks. A realistic discussion on default should start only taking into account the wealth distribution of the country. Since financialization helped concentrate wealth, a fetter to the former would also imply a fetter to the latter, allowing a wider distribution of wealth, urged nowadays by sources such as the Bank for International Settlements, the IMF, or the OECD (see, for instance, Borgouignon [2017], Dabla-Norris et al. [2015], and Cingano [2014]). Technical details of the default should follow the political goal of reducing inequality. It is important to point out that in the aforementioned studies on inequality (and more or less in all the others on the same topic), no realistic policies are proposed for tackling the problem apart from general calls to the government to act. Once again, a default seems the only viable solution.

Due to the political and economic difficulties of a default, we have also discussed monetization. We should observe that this policy is also linked to the balance of forces between government and the markets. Historically, monetization has been considered proof of the subordination of the central bank to the government, but after the 2008 crisis, fiscal prudence has been shattered by bank bailouts, and therefore monetary policy and fiscal policy are forcefully integrated. As Charles Goodhart (2012) noted, "the divorce is over."

Another goal of this paper was a discussion on high levels of public debt in a specific national situation (Italy). As we observed, due to the peculiar governance structure of the EU, all the solutions we proposed for public debt (included monetization) are excluded and we are left either with permanent austerity or a national default. In Europe, national governments have saved their banks (some of them are still, at least partially, publicly owned) without getting much from them in return. The same is true for the ECB, which has 
saved banks using unconventional tools, like cleaning their balance sheets of dangerous assets. Moreover, the creation of the banking union heralds the birth of even bigger banking groups so that the balance of forces will be tilted further toward the markets. In this alreadyuneasy situation, the economic slowdown that seems to be underway at the beginning of 2019 could provoke diverging trends among EU countries and political resentment. Public and private default might ensue, but in a disorderly fashion, wreaking havoc on the markets and on the individual national economies. Because of fiscal austerity, we could be projected into political fight. Without a thorough change in European policies, default is, to paraphrase Churchill, the worst policy except for all the others. Therefore, to prevent default we should ask: Will the German and other dominant EU governments change their opinion in the future? It is true that they accepted policies they had previously ruled out — such as longterm refinancing operations (LTRO), targeted longer-term refinancing operations (TLTRO), and other ECB's unconventional policies (Tooze 2018), as well as bank bailouts-when it was in their immediate interest, while the solution to the problem of public debt is a longterm one that their short-sighted constituencies ${ }^{20}$ do not like. Unless the future of the eurozone is threatened, the austerity framework will probably not be shaken. That is why a discussion on public debt default makes sense. For its part, Italy could use the threat of a sovereign default that would severely hit many European banks (Rosca and Jahanzaib 2018) to force a discussion on a different course for EU economic policy, but it is more likely that such a discussion will come as a consequence of a strong crisis, such as the 2008 one.

As a last point, we think we can extract a final lesson from the history of the BRE. It started without any idea of past theoretical discussion because, as Barro (1996) candidly admitted, he was "blissfully ignorant" of what Ricardo (but also Smith) had to say on the topic. And doubts about the Ricardian nature of the equivalence are still there (Ahiakpor 2013). Other authors before Barro exposed a similar analysis without mentioning Ricardo (for instance, Paul Samuelson [(1955) 1970, 145-54]). The vicissitudes of the BRE show the need for studying the history of economic thought, as well as a historical and institutional approach to economic issues. This would enable us to expand on what mathematical models based on shaky assumptions cannot achieve. As Peter Skott (2012) proposed: "We need broad historical analysis, detailed case studies, institutional work, data collection, statistical

\footnotetext{
${ }^{20}$ For instance, the recent bailout of NordLB (one of the largest state-owned banks) sparked a controversy in the European press because it was conducted without any consideration of the EU rules for public aid (Bufacchi 2019), and because it followed other rounds of help for the same bank (EC 2012; Drost 2017). However, this is unlikely to change the German position on public aid in general.
} 
analysis, mathematical models, experimental evidence, and computer simulations, to mention just some of the useful ingredients." A different and less "insular" (Haldane and Turrell 2018) perspective is needed. History and institutions matter. 


\section{REFERENCES}

Acharya, V. V., I. Drechsler, and P. Schnabl. 2012. "A tale of two overhangs: The nexus of financial sector and sovereign credit risks." Banque de France Financial Stability Review 16: 51-56.

Agarwal, R., and M. Kimbal. 2015. "Breaking Through the Zero Lower Bound." IMF Working Paper No. 15/224. Washington, DC: International Monetary Fund.

Ahiakpor, J. C. W. 2013. "The Modern Ricardian Equivalence Theorem: Drawing the Wrong Conclusions from David Ricardo's Analysis.” Journal of History of Economic Thought 35(1): 77-92.

Alesina, A., M. De Broeck, A. Prati, G. Tabellini, M. Obstfeld, and S. Rebelo. 1992. "Default Risk on Government Debt in OECD Countries." Economic Policy 7(15): 427-63.

Altig, D., and S. Davis. 1989. "Government debt, redistributive fiscal policies, and the interaction between borrowing constraints and intergenerational altruism." Journal of Monetary Economics 24: 3-29.

Andolfatto, D. 2018. "Debt Monetization: Then and Now." Federal Reserve of St. Louis's On the Economy blog, April 2.

Angeletos, G., F. Collard, D. Harris, and B. Diba. 2013. "Optimal Public Debt Management and Liquidity Provision.” NBER Working Paper No. 18800. Cambridge, MA: National Bureau of Economic Research.

Arcand, J., E. Berkes, and U. Panizza. 2012. “Too much finance?” IMF Working Paper No. 12/161. Washington, DC: International Monetary Fund.

Arellano, C., X. Mateos-Planas, and J. V. Rios-Rull. 2013. "Partial Default." Society for Economic Dynamics Meeting Papers 765. Stonybrook, NY: Society for Economic Dynamics.

Arestis, P., and M. Sawyer. 2003. “The Case for Fiscal Policy.” Levy Institute Working Paper No. 382. Annandale-on-Hudson, NY: Levy Economics Institute of Bard College.

- 2004. Re-examining Monetary and Fiscal Policies in the Twenty-First Century. Cheltenham UK: Edward Elgar.

Asonuma, T., and C. Trebesch. 2016. "Sovereign Debt Restructurings: Preemptive or PostDefault." Journal of the European Economic Association 14(1): 175-214.

Associazione Italiana Banche Estere (AIBE). 2017. Foreign Banks and Financial Intermediaries in Italy. Milan: AIBE and Consilia.

Atkinson, T, D. Luttrell, and H. Rosenblum. 2013. "How bad was it? The costs and consequences of the 2007-09 financial crisis." Federal Reserve Bank of Dallas Staff Paper. Dallas: Federal Reserve Bank of Dallas. 
Auerbach, A. J. and Y. Gorodnichenko. 2017. "Fiscal stimulus and fiscal sustainability." NBER Working Paper No. 23789. Cambridge, MA: National Bureau of Economic Research.

Bagehot, W. 1873. Lombard Street: A Description of the Money Market. London: Henry S. King \& Co.

Bailey, M. J. 1993. "Note on Ricardian equivalence." Journal of Public Economics 51(3): 437-46.

Balassone, D., and D. Franco. 2001 "EMU Fiscal Rules: A New Answer to an Old Question?" in Banca d'Italia Workshop on Public Finance February 1-3, Perugia

Bank of Italy. 2018a. “Annual Report on 2017.” Rome: Banca d'Italia.

_. 2018b. “Conti Finanziari.” April. Rome: Banca d'Italia.

Bank for International Settlements (BIS). 2015. “Annual Report.” Basel: Bank for International Settlements.

- 2017. "The Regulatory Treatment of Sovereign Exposure." BIS Discussion Paper No. 425. Basel: Bank for International Settlements.

Banque de France. 2012. "Financial Stability Review, No. 16." Paris: Banque de France.

Barkbu, B., B. Eichengreen, and A. Mody. 2012. "Financial Crises and the Multilateral Response: What the Historical Record Shows." Journal of International Economics 88(2): 422-35.

Barro, R. J. 1974. “Are Government Bonds Net Wealth?” Journal of Political Economy 82(6): 1095-117.

1976. "Perceived wealth in bonds and social security and the Ricardian equivalence theorem: Reply to Feldstein and Buchanan." Journal of Political Economy 84(2): 343-50.

- 1979. "On the Determination of the Public Debt." Journal of Political Economy $87(5)$.

_. 1988. "The Ricardian Approach to Budget Deficit." NBER Working Paper No. 2685. Cambridge, MA: National Bureau of Economic Research.

_. 1996. "Reflections on Ricardian Equivalence.” NBER Working Paper No. 5502. Cambridge, MA: National Bureau of Economic Research.

- 2007. Macroeconomic. A Modern Approach. Mason, OH: South Western College Publishers.

. 2009. "Government Spending is No Free Lunch. Now the Democrats are Peddling Voodoo Economics.” The Wall Street Journal, January 22. 
Barro, R. J., and T., Jin. 2016. "Rare Events and Long-Run Risks.” NBER Working Paper No. 21871. Cambridge, MA: National Bureau of Economic Research.

Barro, R. J., and C. J. Redlick. 2011. "Macroeconomic effects from government purchases and taxes." The Quarterly Journal of Economics 126: 51-102.

Barseghyan, L., and S. Coate. 2014. "Bureaucrats, voters, and public investment." Journal of Public Economics 119: 35-48.

Batini, N., G. Melina, and S. Villa. 2018. "Fiscal buffers, private debt and recession: the good, the bad and the ugly." Temi di discussione della Banca d'Italia No. 1186. Rome: Banca d'Italia.

Bayoumi, T., G. Dell'Ariccia, K. Habermeier, T. Mancini-Griffoli, F. Valencia, and an IMF Staff Team. 2014. "Monetary Policy in the New Normal." IMF Staff Discussion Note No. 14/3. Washington, DC: International Monetary Fund.

Bell, P. F. 2008. "The Asian Economic Crisis and Capitalist Restructuring: Two Approaches." Critical Asian Studies 40(2): 317-22.

Bernanke, B. S. 2010. “Achieving Fiscal Sustainability.” Speech at National Commission on Fiscal Responsibility and Reform, April, 27, Washington, DC.

Bernheim, B. D. 1987. "Ricardian Equivalence: An Evaluation of Theory and Evidence." In S. Fischer (ed.), NBER Macroeconomics Annual. Cambridge, MA: The MIT Press.

Bibow, J. 2013. "Lost at Sea: The Euro Needs a Euro Treasury.” Levy Institute Working Paper No. 70. Annandale-on-Hudson, NY: Levy Economics Institute of Bard College.

Blanchard, O. 2019. "Public Debt and Low Interest Rates." NBER Working Paper No. 25621. Cambridge, MA: National Bureau of Economic Research.

Boitani, A., and S. Perdichizzi. 2018. "Public Expenditure Multipliers in Recessions." DISCE Working Papers No. 68. Milan: Università Cattolica del Sacro Cuore, Dipartimento di Economia e Finanza Dipartimenti e Istituti di Scienze Economiche.

Borensztein, E., and U. Panizza. 2009. "The Costs of Sovereign Default.” IMF Working Paper No. 8/238. Washington, DC: International Monetary Fund.

Bourguignon, F. 2017. "World changes in inequality: an overview of facts, causes, consequences and policies.” BIS Working Paper No. 654. Basel: Bank for International Settlements.

Bresciani-Turroni, C. 1937. The Economics of Inflation. London: George Allen \& Unwin, Ltd.

Brunnermeier, M. 2016. "Financial Dominance.” Paolo Baffi Lecture, December, 1, Rome.

Brunnermeier, M., and Y. Sannikov. 2012. "Redistributive Monetary Policy." Paper prepared for Federal Reserve Bank of Kansas City's Economic Policy Symposium, August 30-September 1, Jackson Hole, WY. 
Bufacchi, I. 2019. "NordLB, a rush against time to save the German 'CARIGE'." (In Italian) Il Sole 24 Ore, January 8.

Buiter, W. H. 1980. "The Macroeconomics of Dr. Pangloss. A Critical Survey of the New Classical Macroeconomics.” Economic Journal 90(357): 34-50. 1993. "Public Debt in the USA.” NBER Working Paper No. 4362. Cambridge, MA: National Bureau of Economic Research.

Buiter, W. H., and E. Rahbari. 2013. "Why do governments default, and why don't they default more often?” CEPR Discussion Paper No. 9492. London: Centre for Economic Policy Research.

Bulow, J., and K. Rogoff. 1989. “A Constant Recontracting Model of Sovereign Debt.” Journal of Political Economy 97(1): 155-78.

Caballero, R. J., and A. Krishnamurthy. 2005. "Bubbles and Capital Flow Volatility: Causes and Risk Management." NBER Working Paper No. 11618. Cambridge, MA: National Bureau of Economic Research.

Calvo, G. A. 1988. "Servicing the Public Debt: The Role of Expectations." American Economic Review 78(4): 647-61.

Caner, M., T. Grennes, and F. Koehler-Geib. 2011. "Finding the Tipping Point: When Sovereign Debt Turns Bad.” In C. A. Primo Braga and G. A. Vincelette (eds.), Sovereign Debt and the Financial Crisis. Will This Time Be Different? Washington, DC: The World Bank.

Canzoneri, M., R. Cumby, and B. Diba. 2013. “Optimal Money and Debt Management: Friedman and Barro Revisited." mimeo. Available at: http://faculty.georgetown.edu/canzonem/pubfin.pdf.

Carli, G. 1995. Pensieri di un ex governatore. Pordenone, Italy: Edizioni Studio Tesi.

Casadio, P., A. Paradiso, and M. Sarcinelli. 2009. "La politica economica: quale aiuto allo sviluppo in Italia?” Economia Italiana 1: 169-81.

Cecchetti, S. G., M. S. Mohanty, and F. Zampolli. 2010. "The future of public debt: prospects and implications.” BIS Working Paper No. 300. Basel: Bank for International Settlements.

Cingano, F. 2014. "Trends in Income Inequality and its Impact on Economic Growth." OECD Social, Employment and Migration Working Papers No. 163. Paris: Organisation for Economic Co-operation and Development.

Cioffi, M., P. Rizza, M. Romanelli, and P. Tommasino. 2019. "Outline of a redistributionfree debt redemption fund for the euro area." Questioni di Economia e Finanza No. 479. Rome: Banca d'Italia.

Claeys, P., R. Moreno, and J. Suriñach. 2012. "Debt, interest rates, and integration of financial markets.” Economic Modelling 29: 48-59. 
Cochrane, J. H. 2010. "Understanding Policy in the Great Recession: Some Unpleasant Fiscal Arithmetic.” NBER Working Paper No. 16087. Cambridge, MA: National Bureau of Economic Research.

Committeri, M., and P. Tommasino. 2018. "Managing sovereign debt restructurings in the eurozone. A note on old and current debates." Questioni di economia e Finanza No. 451. Rome: Banca d'Italia.

Corsetti, G., F. P. Feld, P. R. Lane, L. Reichlin, H. Rey, D. Vayanos, and B. Weder de Mauro. 2015. A new start for the eurozone: Dealing with debt, monitoring the eurozone 1. London: CEPR Press.

Cottarelli, C. 2012. "Fiscal outlook and fiscal sustainability risks." Banque de France Financial Stability Review No. 16. Paris: Banque de France.

Dabla-Norris, E., K. Kochhar, F. Ricka, N. Suphaphiphat, and E. Tsounta. 2015. "Causes and Consequences of Income Inequality: A Global Perspective.” IMF Staff Discussion Note No. 15/03. Washington, DC: International Monetary Fund.

Das, U. S., M. G. Papaioannou, and C. Trebesch. 2012. "Sovereign Debt Restructurings 1950-2010: Literature Survey, Data, and Stylized Facts." IMF Working Paper No. 12/203. Washington, DC: International Monetary Fund.

Debelle, G. 2004. "Macroeconomic implications of rising household debt." BIS Working Paper No. 153. Basel: Bank for International Settlements.

de Castro, F., and J. L. Fernández. 2009. "The Relationship between Public and Private Saving in Spain: Does Ricardian Equivalence Hold?" Documentos de Trabajo Banco de España No. 923. Madrid: Banco de España.

De Cecco, M. 1979. Moneta e Impero. Turin: Einaudi.

Del Giovane, P., A. Nobili, and F. M. Signoretti. 2013. "Supply tightening or lack in demand: Is the sovereign debt crisis different from Lehman?" Paper presented at the workshop "The Sovereign Debt Crisis and the Euro Area," February 15, Rome.

Delpla, J., and J. von Weizsacker. 2010. "The blue bond proposal.” Bruegel Policy Brief No. 420. Brussels: Bruegel.

De Luzenberger R., C. Imbriani, and G. Marini. 1992. "La Sostenibilità del Debito Pubblico: Una Valutazione dei Fondamenti Teorici e delle Metodologie Empiriche." In B. Sitzia, and I. Visco (eds.), Ricerche Applicate e Modelli per la Politica Economica, 2. Rome: Banca d'Italia.

De Paoli, B., G. Hoggarth, and V. Saporta. 2006, “Costs of Sovereign Default.” Financial Stability Paper No. 1. London: Bank of England.

Dequech, D. 2011. "Financial Conventions in Keynes's Theory: The Stock Exchange." Journal of Post Keynesian Economics 33(3): 469-90.

De Rosa, L. 1997. Lo sviluppo economico dell'Italia dal dopoguerra a oggi. Roma: Laterza. 
Detken, C. 1999. "Fiscal Policy Effectiveness and Neutrality Results in a non-Ricardian World.” ECB Working Paper No. 3. Frankfurt am Main: European Central Bank.

Dewatripont, M., J. Rochet, and J. Tirole. 2010. Rebalancing the banks: global lessons from the financial crisis. Princeton, NJ: Princeton University Press.

Diamond, P. A. 1965. "National Debt in a Neoclassical Growth Model." American Economic Review 55(5): 1126-50.

Dobbs, R., S. Lund, J. Woetzel, and M. Mutafchieva. 2015. Debt and not much deleveraging. New York: McKinsey Global Institute.

Dombret, A. 2013. "Criteria for Financial Stability_-The European View." In E. Dombret and O. Lucius (eds.), Stability of the Financial System. Illusion or Feasible Concept? Cheltenham, UK: Edward Elgar.

Dowd, K. 2008. "Moral Hazard and the Financial Crisis." Centre for Risk \& Insurance Studies Discussion Paper Series 2008.VI. Nottingham: Nottingham University Business School.

Drost, F. 2017. “NordLB Posts Record Loss.” Handelsblatt Today, July 4.

Duménil, G., and D. Lévy. 2012. “A Note on Godley-Lavoie's Macro Framework.” mimeo. Paris: Cepremap. Available at: http://www.cepremap.fr/membres/dlevy/dle2012i.pdf.

Economic Policy Institute (EPI). 2017. "The potential macroeconomic benefits from increasing infrastructure investment.” EPI blog, July 18.

Eichengreen, B. 1991. "Historical Research in International Lending and Debt." Journal of Economic Perspectives 5(2): 149-69.

Eisner, R. 1989. "Budget Deficits: Rhetoric and Reality." Journal of Economic Perspectives 3(2): 73-93.

Ejsing, J., and W. Lemke. 2011. "The Janus-headed salvation: Sovereign and bank credit risk premia during 2008-2009.” Economics Letters 110(1): 28-31.

European Central Bank (ECB). 2012a. "Speech by Mario Draghi, President of the European Central Bank.” European Central Bank Global Investment Conference, July 26, London.

_ 2012b. "Main Elements of the Fiscal Compact." ECB Monthly Bulletin, March. Frankfurt am Main: European Central Bank.

—. 2016. "Economic Bulletin, No. 2.” Frankfurt am Main: European Central Bank.

European Commission (EC). 2011. "Quarterly Report on the Euro Area.” October. Brussels: European Commission.

2012. "State aid: Commission approves restructuring aid for German bank NORD/LB.” Press Release, July 25. Brussels: European Commission. 
- 2017. "State aid: How the EU rules apply to banks with a capital shortfall." Memo 17-1792. Brussels: European Commission.

European Parliament Directorate General for Internal Policies (EU DGIP). 2011. Eurobonds: Concepts and Implications. Brussels: European Commission.

Evans, G. W., S. Honkapohja, and K. Mitra. 2012. "Does Ricardian Equivalence Hold When Expectations Are Not Rational?" Journal of Money, Credit and Banking 44(7): 1259-83.

Fantacci, L. 2005. La moneta, Storia di un 'istituzione mancata. Venice: Marsilio.

Fernandez, A., M. W. Klein, A. Rebucci, M. Schindler, and M. Uribe. 2016. "Capital Control Measures: A New Dataset.” IMF Economic Review 64(3): 548-74.

Fiebiger, B., and M. Lavoie. 2017. "The IMF and the New Fiscalism: Was there a U-turn?" European Journal of Economics and Economic Policies 14(3): 314-32.

Forster, J. D. 2009. “Keynesian Policies Stimulate Debate and Debt, Not Employment.” CESifo Forum 10(2): 20-25.

Freixas, X., and J. Rochet. 2008. Microeconomics of Banking. Cambridge, MA: The MIT Press.

Furceri D., and A. Zdzienicka. 2012. "The Consequences of Banking Crises for Public Debt.” International Finance 15(3): 289-307.

Gogas, P., B. Plakandaras, and T. Papadimitriou. 2014. "Public debt and private consumption in OECD countries." The Journal of Economic Asymmetries 11(June): $1-7$.

Goodhart, C. 2012. "Monetary policy and public debt." Banque de France Financial Stability Review No. 16. Paris: Banque de France.

Gourinchas, P., and O. Jeanne. 2012. "Global Safe Assets." Paper prepared for the 11th BIS Annual Conference, June 20-21, Lucerne.

Grande, G., S. Masciantonio, and A. Tiseno. 2013. "The elasticity of demand for sovereign debt. Evidence from OECD Countries (1995-2011).” In Banca d'Italia (ed.), The sovereign debt crisis and the euro area. Rome: Banca d'Italia.

Greenspan, A. 2009. "Inflation is the big threat to a sustained recovery." Financial Times, June 26.

Greenwood, R. S., G. Hanson, J. S. Rudolph, and L. H. Summers. 2014. “Government Debt Management at the Zero Lower Bound." Hutchins Center on Fiscal and Monetary Policy at Brookings Working Paper No. 5. Washington, DC: Brooking Institution.

Grossman, H., and J. van Huyck. 1988. "Sovereign Debt as a Contingent Claim: Excusable Default, Repudiation, and Reputation.” American Economic Review 78(5): 1088-97. 
Haldane, A. G. 2009. "Banking on the State.” BIS Review No. 139. Basel: Bank for International Settlements.

Haldane, A. G., and A. E. Turrell. 2018. "An interdisciplinary model for macroeconomics." Oxford Review of Economic Policy 34 (1-2): 219-51.

Hanusch, H., L. S. Chakrarborty, and S. Khurana. 2017. "Fiscal Policy, Economic Growth, and Innovation: An Empirical Analysis of G20 Countries." Levy Institute Working Paper No. 883. Annandale-on-Hudson, NY: Levy Economics Institute of Bard College.

Haug, A. A. 2016. "A New Test of Ricardian Equivalence Using the Narrative Record on Tax Changes.” University of Otago Economics Discussion Papers No. 1607. Otago, New Zealand: University of Otago.

Hayo, B., and F. Neumeier. 2016. "The (In)Validity of the Ricardian Equivalence Theorem-Findings from a Representative German Population Survey.” Joint Discussion Paper Series in Economics by the Universities of Aachen, Gießen, Göttingen, Kassel, Marburg and Siegen No. 11. Marburg: School of Business and Economics.

Hemming, R., M. Kell, and S. Mahfouz. 2002. "The Effectiveness of Fiscal Policy in Stimulating Economic Activity: A Review of the Literature." IMF Working Paper No. 02/208. Washington, DC: International Monetary Fund.

Herndon, T., M. Ash, and R. Pollin. 2013. "Does High Public Debt Consistently Stifle Economic Growth? A Critique of Reinhart and Rogoff." Political Economy Research Institute (PERI) Working Paper No. 322. Amherst, MA: University of Massachusetts.

Holmstrom, B., and J. Tirole. 1998. "Private and public supply of liquidity." Journal of Political Economy 106(1): 1-40.

Hume, D. (1752) 1970. Hume's Writings on Economics, edited by Eugene Rotwein. Madison, WI: University of Wisconsin Press.

International Monetary Fund (IMF). 2006. Financial Soundness Indicators. Compilation Guide. Washington, DC: International Monetary Fund.

_. 2013a. "Global Impact and Challenges of Unconventional Monetary Policies." IMF Policy Paper. Washington, DC: International Monetary Fund.

- 2013b. "Cyprus. First review under the extended Arrangement under the extended Fund Facility and request for Modification of Performance Criteria." IMF Country Report No. 13/293. Washington, DC: International Monetary Fund.

- 2015. World Economic Outlook, April. Washington, DC: International Monetary Fund.

_ 2017. "Negative Interest Rate Policies_-Initial Experiences and Assessments." IMF Policy Paper. Washington, DC: International Monetary Fund. 
_ 2018. “Global Financial Stability Report.” April. Washington, DC: International Monetary Fund.

Jacobs, B. 2012. "Understanding tax distortions and Ricardian equivalence.” BasJacobs blog, January 2.

Jakab, Z., and M. Kumhof. 2015. "Banks are not intermediaries of loanable funds - and why this matters." Bank of England Working Paper No. 529. London: Bank of England.

Janssen, R. 2016. "German Economy Ministry Backs Up OECD Call For Public Investment Stimulus." Social Europe blog, December 20.

Johnson, S., and J. Kwak. 2010. 13 Bankers. The Wall Street Takeover and the Next Financial Meltdown. New York: Vintage Books.

Jordà, O., M. Schularick, and A. M. Taylor. 2015. "Betting the house: Monetary policy, mortgage booms and housing prices." VoxEU blog, February 18.

- 2016. "Macrofinancial History and the New Business Cycle Facts." Federal Reserve Bank of San Francisco Working Paper 2016-23. San Francisco: Federal Reserve Bank of San Francisco.

Juselius, M., and M. Drehmann. 2015. "Leverage dynamics and the real burden of debt." BIS Working Paper No. 501. Basel: Bank for International Settlements.

Keynes, J. M. (1936) 2018. “The General Theory of Employment, Interest, and Money.” In D. Moggridge (ed.) The Collected Writings of John Maynard Keynes, Vol. VII. London: Macmillan.

Kindleberger, C. P. 1987. Storia della finanza nell'Europa occidentale. Rome: Laterza.

King, R. G., and R. Levine. 1993. "Finance and Growth: Schumpeter Might Be Right.” The Quarterly Journal of Economics 108(3): 717-37.

Konzelmann, S. 2014. "The Political Economics of Austerity." Cambridge Journal of Economics 38(4): 701-41.

Koo, R. C. 2008. The Holy Grail of Macroeconomics: Lessons from Japan's Great Recession. New York: Wiley \& Sons, Ltd.

Korinek, A., and J. Kreamer. 2013. "The Redistributive Effects of Financial Deregulation." IMF Working Paper No. 13/247. Washington, DC: International Monetary Fund.

Laffer, A. 2009. “Get Ready for Inflation and Higher Interest Rates.” Wall Street Journal, June 11.

Law, J. 1934. Oeuvres Complètes. Paris: Librairie du Recueil Sirey.

Le Heron, E. 2012. “A Debate with Wynne Godley on the Neutrality of Fiscal Policy.” In D. B. Papadimitriou and G. Zezza (eds.), Contributions in stock-flow modeling: essays in honor of Wynne Godley. London: Palgrave Macmillan. 
Lerner, A. P. 1943. "Functional Finance and the Federal Debt." Social Research 10: 38-51.

Li, Y., R. Olivares-Caminal, and U. Panizza. 2011. "Avoiding Avoidable Debt Crises: Lessons from Recent Defaults." In C. A. Primo Braga and G. A. Vincelette (eds.), Sovereign Debt and the Financial Crisis. Will This Time Be Different? Washington, DC: World Bank.

Lippi, F., and F. Schivardi. 2014. "Le conseguenze di un ripudio del debito." Lavoce.Info blog, May 16.

Liviatan. N. 1982. "Neutrality of Government Bonds Reconsidered." Journal of Public Economics 19: 261-70.

Marx, K. (1867) 1887. Capital: A Critique of Political Economy. Volume I, Book One: The Process of Production of Capital. Moscow: Progress Publishers.

Mastromatteo, G., and L. Esposito. 2015. "The Two Approaches to Money: Debt, Central Banks, and Functional Finance.” Levy Institute Working Paper No. 855. Annandaleon-Hudson, NY: Levy Economics Institute of Bard College.

_ 2016. "Minsky at Basel: A Global Cap to Build an Effective Postcrisis Banking Supervision Framework." Levy Institute Working Paper No. 875. Annandale-onHudson, NY: Levy Economics Institute of Bard College.

_ 2017a. "Banking on ELR: How Hyman Minsky's Ideas Can Help Tackle Unemployment.” Journal of Economic Issues 51(3): 635-50.

- 2017b. "Rethinking Economic Policy in the Age of Financialization: Why the Barro-Ricardo Theory Cannot Make Sense." Binzagr Global Institute for Sustainable Prosperity Policy Note No. 116. Available at: http://www.binzagr-institute.org/wpcontent/uploads/2017/09/PN-116.pdf

Mazuccato, M. 2013. The Enterpreunerial State. London: Demos.

Merler, S., and J. Pisani-Ferry. 2012. "Hazardous tango: sovereign-bank interdependence and financial stability in the euro area." Banque de France Financial Stability Review No. 16. Paris: Banque de France.

Metzler, L. A. 1951. "Wealth, Saving, and the Rate of Interest." Journal of Political Economy 59(2): 93-116.

Minenna, M. 2014. "Una via flessibile agli eurobond.” LeftWing, July 14.

- 2018. "Il paradosso del Giappone: debito enorme, rischi minimi." Il Sole 24 Ore, December 24.

Minenna, M., G. M. Boi, and P. Verzella. 2016. La moneta incompiuta. Il futuro dell'euro e le soluzioni per l'Eurozona. Rome: Ediesse.

Minsky, H. P. 1982. “The Financial Instability Hypothesis.” Levy Institute Working Paper No. 74. Annandale-on-Hudson, NY: Levy Economics Institute of Bard College. 
Mody, A. 2013. "Sovereign debt and its restructuring framework in the eurozone." Oxford Review of Economic Policy 29(4): 715-44.

Nickel, C., and I. Vansteenkiste. 2008. "Fiscal Policies, the Current Account and Ricardian Equivalence.” ECB Working Paper No. 93. Frankfurt am Main: European Central Bank.

Nikiforos, M., and G. Zezza. 2017. "Stock-flow Consistent Macroeconomic Models: A Survey.” Levy Institute Working Paper No. 891. Annandale-on-Hudson, NY: Levy Economics Institute of Bard College.

Nispi Landi, V., and A. Schiavone. 2018. "The effectiveness of capital controls." Temi di discussione della Banca d'Italia No. 1200. Rome: Banca d'Italia.

O’Driscoll, Jr., G. P. 1977. “The Ricardian Non-Equivalence Theorem.” Journal of Political Economy 85(1): 207-10.

Organisation for Economic Co-operation and Development (OECD). 2017. Economic Outlook, Issue 2. Paris: Organisation for Economic Co-operation and Development.

Orléan, A. 2004. Analyse économique des conventions. Paris: Presses Universitaires de France.

Ostry, J. D., A. R. Ghosh., and R. Espinoza. 2015. "When Should Public Debt Be Reduced?” IMF Staff Discussion Note No. 15/10. Washington, DC: International Monetary Fund.

Panetta, F. 2018. "Il sistema bancario italiano nel quadro dell'Unione bancaria europea." Rome: Banca d'Italia.

Parello, C. P., and V. Visco. 2012. "The European Redemption Fund: A Comparison of Two Proposals." Munich Personal RePEc Archive Paper No. 42232. Munich: Munich University.

Paris, P., and C. Wiplosz. 2013. "To end the eurozone crisis, bury the debt forever." VOX CEPR Policy Portal blog, August 6.

Parrado-Martinez, P., A. Partal Ureña, and P. Gómez Fernández-Aguado. 2014. "Usefulness of Financial Soundness Indicators for Risk Assessment: The Case of EU Member Countries." Universidad Pablo de Olavide Working Paper No. 14.01. Sevilla: Universidad Pablo de Olavide.

Phillips Erb, K. 2011. “I'm From the Government and I'm Here to Help.” Forbes, October 21.

Pozzi, L. 2006. "Ricardian equivalence under imperfect information.” Journal of Public Economics 90(10-11): 2009-26.

Praet, P. 2011. "Economic, financial and monetary stability in Europe: reinforcing our policy instruments." 10th Annual Bank for International Settlements Conference, June 23-24, Lucerne. 
Rafferty, D. T. 2017. “Analyzing the IMF's 'New' Institutional View for Regulating International Capital Flows Using Minsky and Kregel: Do They Finally Get It?" International Journal of Political Economy 47(2-3): 113-27.

Rajan, R. G., and L. Zingales. 1998. "Financial Dependence and Growth.” The American Economic Review 88(3): 559-86.

Reich, R. 2019. "Socialism for the Rich, Capitalism for the Rest." Yes!, April, 26. Available at: https://www.yesmagazine.org/new-economy/socialism-for-rich-capitalismamerican-economy-20190426.

Reinhart, C. M., and K. S. Rogoff. 2009. This Time Is Different Eight Centuries of Financial Folly. Princeton, NJ: Princeton University Press.

- 2011. "From financial crash to debt crisis." American Economic Review 101(5): 1676-706.

- 2013. "Financial and Sovereign Debt Crises: Some Lessons Learned and Those Forgotten.” IMF Working Paper No. 13/266. Washington, DC: International Monetary Fund.

Reinhart, C. M., and S. M. Sbrancia. 2011. "The liquidation of government debt.” NBER Working Paper No. 16893. Cambridge, MA: National Bureau of Economic Research.

Revell, J. 1975. Solvency and Regulation of Banks. Cardiff: University of Wales Press.

Rey, G., and P. Peluffo (eds.). 1995. Dialogo tra un professore e la Banca d'Italia. Florence: Vallecchi.

Ricciuti, R. 2003. “Assessing Ricardian Equivalence.” Journal of Economic Surveys 17(1): $55-78$.

Richardson, D. R. 2015. "What does 'too much government debt' mean in a stock-flow consistent model?" Real-World Economics Review 73: 2-15.

Rigon, M., and F. Zanetti. 2017. "Optimal monetary policy and fiscal interactions in a nonRicardian economy." Tema di discussione della Banca d'Italia No. 1155. Rome: Banca d'Italia.

Röhn, O. 2010. "New Evidence on the Private Saving Offset and Ricardian Equivalence." OECD Economics Department Working Papers No. 762. Paris: Organisation for Economic Co-operation and Development.

Röhrs, S., and C. Winter. 2015. "Public versus private provision of liquidity: Is there a tradeoff?” Journal of Economic Dynamics \& Control 53: 314-39.

Romer, P. 2016. “The Trouble with Macroeconomics.” Paul Romer blog, September 14. 
Rosca, M., and M. Jahanzaib. 2018. "French, Spanish banks most exposed to Italian bonds outside Italy." S\&P Market Intelligence, May 18. Available at: https://platform.mi.spglobal.com/web/client?auth=inherit\&sf190094156=1\#news/arti cle? $\mathrm{id}=44653885 \&$ cdid=A-44653885-10794.

Saito, I. 2016. "Fading Ricardian Equivalence in Ageing Japan.” IMF Working Paper No. 194. Washington, DC: International Monetary Fund.

Samuelson, P. (1955) 1973. "Diagrammatic Exposition of a Theory of Public Expenditure." In S. Estrin and A. Marin (eds.), Readings in Economics. New York: Mc-Graw Hill.

Schlicht, E. 2013. "Unexpected Consequences of Ricardian Expectations.” Metroeconomica 64(3): 498-512.

—. 2014. "Unexpected Consequences of Ricardian Expectations—Erratum." Metroeconomica 65(1): 191-94.

Seater, J. J. 1993. “Ricardian equivalence.” Journal of Economic Literature 31(1): 142-90.

Skott, P. 2012. "Pluralism, the Lucas Critique and the Integration of Macroeconomics and Microeconomics." Review of Political Economy 26(4): 503-15.

Smetters, K. 1999. "Ricardian equivalence: long-run Leviathan.” Journal of Public Economics 73(3): 395-421.

Smith, A. (1776) 1904. An inquiry into the nature and causes of the wealth of nations. London: Henry Frowde.

Sotiropoulos, D. M., J. Milios, and S. Lapatsioras. 2014. “An Outline of a Progressive Resolution to the Euro-area Sovereign Debt Overhang: How a Five-year Suspension of the Debt Burden Could Overthrow Austerity." Levy Institute Working Paper No. 819. Annandale-on-Hudson, NY: Levy Economics Institute of Bard College.

Stiglitz, J. E. 2001. "Foreword.” In K. Polanyi (ed.), The Great Transformation. Boston: First Beacon.

- 2014. "Reconstructing Macroeconomic Theory to Manage Economic Policy." In E. Laurent and J. Le Cacheux (eds.), Fruitful Economics. London: Palgrave Macmillan.

- 2015. "Monetary Policy in a Multi-Polar World." In J. E. Stiglitz and R. S. Gürkaynak (eds.), Taming Capital Flows: Capital Account Management in an Era of Globalization. London: Springer.

Tagkalakis, A. O. 2014. "Financial stability indicators and public debt developments." Quarterly Review of Economic and Finance 54(2014): 158-79.

Taleb, N. N. 2007. The Black Swan: The Impact of the Highly Improbable. New York: Random House.

Tatom, J. A. 2009. “The limits of fiscal policy.” CESifo Forum 10(2): 14-19. 
Taylor, A. M. 2012. “The Great Leveraging.” NBER Working Paper No. 18290. Cambridge, MA: National Bureau of Economic Research.

Tcherneva, P. R. 2008. "The Return of Fiscal Policy: Can the New Developments in the New Economic Consensus Be Reconciled with the Post-Keynesian View?" Levy Institute Working Paper No. 539. Annandale-on-Hudson, NY: Levy Economics Institute of Bard College.

- 2012. "The Role of Fiscal Policy: Lessons from Stabilization Efforts in the United States during the Great Recession." International Journal of Political Economy 41(2): 5-25.

Terzi, A. 2014. "When Good Intentions Pave the Road to Hell: Monetization Fears and Europe's Narrowing Options." Levy Institute Working Paper No. 810. Annandaleon-Hudson, NY: Levy Economics Institute of Bard College.

Tirole, J. 2012. "The euro crisis: some reflections on institutional reform." Banque de France Financial Stability Review 16: 225-42.

Tobin, J. 1952. "Asset Holdings and Spending Decisions." The American Economic Review 42(2): 109-23.

Tonveronachi, M. 2016. "Three proposals for revitalising the European Union.” PSL Quarterly Review 69(279): 301-36.

—. 2018. "European Sovereign Bond-Backed Securities: An Assessment and an Alternative Proposal.” Levy Institute Public Policy Brief No. 145. Annandale-onHudson, NY: Levy Economics Institute of Bard College.

Tooze, A. 2018. Crashed. How a Decade of Financial Crises Changed the World. New York: Penguin.

Trebesch, C., and M. Zabel. 2017. "The Output Costs of Hard and Soft Sovereign Default." European Economic Review 92(C): 416-32.

Ülgen, F. 2014. "Financial instability and functional finance. A Lerner-Minsky perspective." In L. Mamica and P. Tridico (eds.), Economic policy and the financial crisis. London: Routledge.

US Government Printing Office (US GPO). 1924. "Recognition of Russia: Hearings before the United States Senate Committee on Foreign Relations." Subcommittee on S. Res. 50, 68th Congress, First Session. Parts 1-2. Washington, DC: US Government Printing Office.

Varoufakis, Y., S. H. Holland, and J. K. Galbraith. 2013. “A Modest Proposal for Resolving the eurozone Crisis." Available at: https://varoufakis.files.wordpress.com/2013/07/amodest-proposal-for-resolving-the-eurozone-crisis-version-4-0-final1.pdf.

Vines, S., and S. Wills. 2018. "The rebuilding macroeconomic theory project: an analytical assessment." Oxford Review of Economic Policy 34(1-2): 1-42. 
Visco, I. 2017. "Economic development and financial stability: the constraint of public debt." (In Italian) Speech at Banca d'Italia 63rd Convegno di Studi Amministrativi, September 21-23, Varenna.

_ 2018a. “The Governor's Concluding Remarks.” Rome: Banca d'Italia.

_. 2018b. "Banks and finance after the crisis: lessons and challenges." (In Italian) Lectio Magistralis, Università degli studi “Tor Vergata,” Rome: Banca d'Italia.

Woodford, M. 1990. "Public Debt as Private Liquidity." American Economic Review 80(1990): 382-88.

Zezza, G. 2009. "Fiscal Policy and the Economics of Financial Balances.” Levy Institute Working Paper No. 569. Annandale-on-Hudson, NY: Levy Economics Institute of Bard College.

— 2012. "Godley and Graziani: Stock-flow Consistent Monetary Circuits." In D. B. Papadimitriou and G. Zezza (eds.), Contributions to Stock-Flow Modeling: Essays in Honor of Wynne Godley. London: Palgrave MacMillan.

Zezza, G., and F. Zezza. 2019. "On the Design of Empirical Stock-Flow-Consistent Models." Levy Institute Working Paper No. 919. Annandale-on-Hudson, NY: Levy Economics Institute of Bard College. 